\title{
Total Synthesis of SNF4435 C and D
}

\author{
Christopher M. Beaudry and Dirk Trauner \\ Department of Chemistry, University of California; Berkeley, CA 94720-1460.
}

\section{Supporting Information}

General Experimental Details: All reactions were carried out under an atmosphere of $\mathrm{N}_{2}$ in flame dried glassware. External bath temperatures were used to record all reaction mixture temperatures. Tetrahydrofuran (THF), methylene chloride $\left(\mathrm{CH}_{2} \mathrm{Cl}_{2}\right)$, and ethyl ether $\left(\mathrm{Et}_{2} \mathrm{O}\right)$ were dried by passage through activated alumina columns. Triethylamine $\left(\mathrm{Et}_{3} \mathrm{~N}\right)$, benzene $(\mathrm{PhH}), i \operatorname{Pr}_{2} \mathrm{EtN}, i \operatorname{PrNH}$, and acetonitrile $(\mathrm{MeCN})$ were distilled from calcium hydride. Dimethyl formamide (DMF) was degassed with a stream of $\mathrm{N}_{2}$, dried over molecular sieves, and used without further purification. $n$-BuLi was titrated using diphenylacetic acid in THF. All other solvents and reagents were purchased and used without further purification.

Instrumentation: FT-IR spectra were obtained on $\mathrm{NaCl}$ plates with an ATI Mattson Gemini spectrometer. Proton and carbon NMR spectra $\left({ }^{1} \mathrm{H}\right.$ NMR and ${ }^{13} \mathrm{C}$ NMR) were recorded in deuterated solvents on Bruker AVB-400 or DRX-500 spectrometers and calibrated to the residual solvent peak. Multiplicities are abbreviated as follows: $\mathrm{s}=$ singlet, $\mathrm{d}=$ doublet, $\mathrm{t}=$ triplet, $\mathrm{m}=$ multiplet, $\mathrm{app}=$ apparent, $\mathrm{br}=$ broad. Melting points are uncorrected.

Unsaturated nitrile S1:

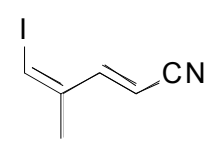

(Z)-3-Iodo-2-methylprop-2-en-1-ol ${ }^{1}(201 \mathrm{mg}, 1.02 \mathrm{mmol})$ was dissolved in $\mathrm{CH}_{2} \mathrm{Cl}_{2}$ (8 $\mathrm{mL}$ ) and DMSO $(2 \mathrm{~mL})$. Benzoic acid $(311 \mathrm{mg}, 2.55 \mathrm{mmol}), \mathrm{Ph}_{3} \mathrm{P}=\mathrm{CHCN}(770 \mathrm{mg}, 2.55$ $\mathrm{mmol}$ ), and Dess-Martin periodinane $(645 \mathrm{mg}, 1.52 \mathrm{mmol})$ were added at rt. The mixture became hot, and was allowed to stir for an additional hour. A 1:1 solution of saturated aqueous $\mathrm{NaHCO}_{3}$ :saturated aqueous $\mathrm{Na}_{2} \mathrm{~S}_{2} \mathrm{O}_{3}(8 \mathrm{~mL})$ was added. The layers were separated and the aqueous phase was extracted with $\mathrm{CH}_{2} \mathrm{Cl}_{2}(2 \times 10 \mathrm{~mL})$. The organic layers were combined, dried over $\mathrm{MgSO}_{4}$, filtered through a pad of silica, and concentrated in vacuo. Purification by silica gel chromatography $\left(10: 1\right.$ hexanes:Et $\left.\mathrm{t}_{2} \mathrm{O}\right)$ gave $\mathbf{S 1}(103 \mathrm{mg}, 46 \%)$ and the corresponding $Z$ isomer (37 $\mathrm{mg}, 16 \%$ ) as white solids. Data for S1: $\mathrm{R}_{\mathrm{f}} 0.46$ (5:1 hexanes:EtOAc); $\mathrm{mp} 63-64{ }^{\circ} \mathrm{C}$; IR 2213, $1603 \mathrm{~cm}^{-1} ;{ }^{1} \mathrm{H}$ NMR $\left(\mathrm{CDCl}_{3}, 400 \mathrm{MHz}\right) \delta 7.41(\mathrm{~d}, 1 \mathrm{H}, J=13 \mathrm{~Hz}), 6.74(\mathrm{~s}, 1 \mathrm{H}), 5.53(\mathrm{~d}, 1 \mathrm{H}, J=13 \mathrm{~Hz}), 1.97$ (s, 3H); ${ }^{13} \mathrm{C}$ NMR $\left(\mathrm{CDCl}_{3}, 100 \mathrm{MHz}\right) \delta 150.9,140.1,117.7,100.5,90.0,20.2$; HRMS (EI) Calculated for $\mathrm{C}_{6} \mathrm{H}_{6} \mathrm{NI}\left(\mathrm{M}^{+}\right)$: 218.954501. Found: 218.955058 .

Stannane 7b: 


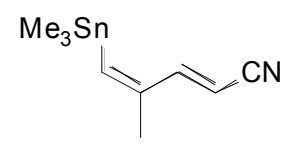

To a solution of iodide $\mathbf{S 1}(103 \mathrm{mg}, 0.470 \mathrm{mmol})$ in $\mathrm{PhH}(4.7 \mathrm{~mL})$ was added $\mathrm{Me}_{6} \mathrm{Sn}_{2}$ (231 mg, $0.705 \mathrm{mmol}), i \operatorname{Pr}_{2} \mathrm{EtN}(24 \mu \mathrm{L}, 0.141 \mathrm{mmol})$, and $\mathrm{Pd}\left(\mathrm{PPh}_{3}\right)_{4}(27 \mathrm{mg}, 0.024$ mmol). The mixture was heated to $75{ }^{\circ} \mathrm{C}$ for 20 hours, upon which time the reaction mixture was filtered through basic alumina and concentrated on a rotary evaporator. The residue was dissolved in $\mathrm{MeCN}(10 \mathrm{~mL})$ and washed with hexanes $(3 \times 5 \mathrm{~mL})$. The $\mathrm{MeCN}$ layer was then concentrated to give $\mathbf{7 b}(71 \mathrm{mg}, 59 \%)$ as a yellow oil. Data for $\mathbf{7 b}$ : $\mathrm{R}_{\mathrm{f}} 0.51$ (10:1 hexanes:EtOAc); IR $2217 \mathrm{~cm}^{-1} ;{ }^{1} \mathrm{H}$ NMR $\left(\mathrm{CDCl}_{3}, 400 \mathrm{MHz}\right) \delta 7.04(\mathrm{~d}, 1 \mathrm{H}$, $J=16 \mathrm{~Hz}), 6.54(\mathrm{~m}, 1 \mathrm{H}), 5.36(\mathrm{~d}, 1 \mathrm{H}, J=16 \mathrm{~Hz}), 1.92(\mathrm{~m}, 3 \mathrm{H}), 0.25(\mathrm{~m}, 9 \mathrm{H}) ;{ }^{13} \mathrm{C} \mathrm{NMR}$ $\left(\mathrm{CDCl}_{3}, 100 \mathrm{MHz}\right) \delta 153.3,148.4,147.6,118.5,97.0,21.9,-9.7$; HRMS (EI) Calculated for $\mathrm{C}_{8} \mathrm{H}_{12} \mathrm{NSn}\left(\mathrm{M}-\mathrm{Me}^{+}\right)$: 241.999173. Found: 241.999601. Anal. Calculated for $\mathrm{C}_{9} \mathrm{H}_{15} \mathrm{NSn}$ : C, 42.24\%; H, 5.91\%; N, 5.47\%. Found: C, 42.55\%; H, 6.03\%; N, 5.18\%.

Nitrile 8b:

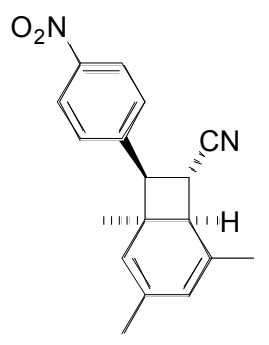

To a solution of iodide 6 (218 $\mathrm{mg}, 0.848 \mathrm{mmol})$ and stannane $7 \mathbf{b}(217 \mathrm{mg}, 0.848 \mathrm{mmol})$ in DMF $(9 \mathrm{~mL})$ at $\mathrm{rt}$ was added $\mathrm{Pd}\left(\mathrm{MeCN}_{2} \mathrm{Cl}_{2}(22 \mathrm{mg}, 0.085 \mathrm{mmol})\right.$. The mixture was allowed to stir for 2 hours, upon which time it was diluted with EtOAc and water. The layers were separated and the aqueous layer was extracted with EtOAc $(2 \times 10 \mathrm{~mL})$. The combined organic layers were dried over $\mathrm{MgSO}_{4}$, filtered, and concentrated in vacuo. Purification by silica gel chromatography (4:1 hexanes:EtOAc) gave $\mathbf{8 b}(120 \mathrm{mg}, 48 \%)$ as a yellow solid which can be recrystallized from $\mathrm{CH}_{2} \mathrm{Cl}_{2} /$ hexanes. Data for $\mathbf{8 b}$ : $\mathrm{R}_{\mathrm{f}} 0.50$ (5:1 hexanes:EtOAc); mp 134-135 ${ }^{\circ} \mathrm{C}$; IR $2233,1522,1348 \mathrm{~cm}^{-1} ;{ }^{1} \mathrm{H}$ NMR $\left(\mathrm{CDCl}_{3}, 400\right.$ MHz) $\delta 8.20(\mathrm{~d}, 2 \mathrm{H}, J=9 \mathrm{~Hz}), 7.31$ (d, 2H, $J=9 \mathrm{~Hz}), 5.50$ (s, 1H), 4.43 (s, 1H), 3.79 (d, $1 \mathrm{H}, J=10 \mathrm{~Hz}$ ), 3.37 (app t, $1 \mathrm{H}, J=10 \mathrm{~Hz}), 2.86(\mathrm{~d}, 1 \mathrm{H}, J=10 \mathrm{~Hz}), 1.85(\mathrm{~s}, 3 \mathrm{H}), 1.62$ (s, $3 \mathrm{H}), 1.29(\mathrm{~s}, 3 \mathrm{H}) ;{ }^{13} \mathrm{C} \mathrm{NMR}\left(\mathrm{CDCl}_{3}, 100 \mathrm{MHz}\right) \delta 147.2,143.0,132.2,131.8,127.8$, 123.7, 123.2, 120.3, 120.0, 57.3, 47.1, 46.4, 29.3, 28.2, 21.9, 21.3; HRMS (EI) Calculated for $\mathrm{C}_{18} \mathrm{H}_{18} \mathrm{~N}_{2} \mathrm{O}_{2}\left(\mathrm{M}^{+}\right)$: 294.136828. Found: 294.136777. Anal. Calculated for $\mathrm{C}_{18} \mathrm{H}_{18} \mathrm{~N}_{2} \mathrm{O}_{2}$ : C, 73.45\%; H, 6.16\%; N, 9.52\%. Found: C, 73.21\%; H, 6.15\%; N, 9.21\%.

Stannane 9:

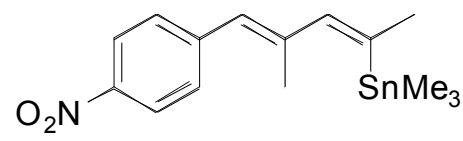


To a solution of iodide $\mathbf{6}^{2}(249 \mathrm{mg}, 0.757 \mathrm{mmol})$ in HMPA $(8 \mathrm{~mL})$ at $\mathrm{rt}$ was added $\mathrm{Me}_{3} \mathrm{SnSnMe}_{3}(372,1.14 \mathrm{mmol})$ and $\mathrm{Pd}(\mathrm{MeCN})_{2} \mathrm{Cl}_{2}(20 \mathrm{mg}, 0.076 \mathrm{mmol})$. The mixture was stirred for $3 \mathrm{~h}$ upon which time the mixture was diluted with $\mathrm{Et}_{2} \mathrm{O}(25 \mathrm{~mL})$ and $\mathrm{H}_{2} \mathrm{O}$ $(25 \mathrm{~mL})$. The layers were separated and the organic layer was washed with additional $\mathrm{H}_{2} \mathrm{O}(25 \mathrm{~mL})$. The combined aqueous layers were extracted with $\mathrm{Et}_{2} \mathrm{O}(2 \times 25 \mathrm{~mL})$. The organic layers were combined, dried over $\mathrm{Na}_{2} \mathrm{SO}_{4}$, filtered, and concentrated. Purification by silica gel chromatography $\left(40: 1\right.$ hexanes: $\left.\mathrm{E}_{2} \mathrm{O}\right)$ gave stannane $9(171 \mathrm{mg}$, $62 \%$ ) as an orange liquid which solidifies upon standing at $-20{ }^{\circ} \mathrm{C}$. Data for 9 : $\mathrm{R}_{\mathrm{f}} 0.26$ (40:1 hexanes: $\left.\mathrm{Et}_{2} \mathrm{O}\right)$; mp $58-59{ }^{\circ} \mathrm{C}$; IR $1516,1342 \mathrm{~cm}^{-1} ;{ }^{1} \mathrm{H}$ NMR $\left(\mathrm{CDCl}_{3}, 500 \mathrm{MHz}\right) \delta$ 8.19 (d, 2H, $J=9 \mathrm{~Hz}), 7.41$ (d, 2H, $J=9 \mathrm{~Hz}), 6.79-6.53(\mathrm{~m}, 1 \mathrm{H}), 6.41(\mathrm{~s}, 1 \mathrm{H}), 2.05$ (m, $3 \mathrm{H}), 1.98$ (s, 3H), 0.26-0.08 (m, 9H); ${ }^{13} \mathrm{C}$ NMR (CDCl $\left.3,125 \mathrm{MHz}\right) \delta 145.8,144.8,144.6$, $144.3,144.1,129.5,124.5,123.6,27.0,18.8,-7.85 ;{ }^{119} \mathrm{Sn} \mathrm{NMR}\left(\mathrm{CDCl}_{3}, 186 \mathrm{MHz}\right) \delta-$ 38.1; HRMS (FAB) Calculated for $\mathrm{C}_{14} \mathrm{H}_{18} \mathrm{NO}_{2} \mathrm{Sn}\left(\mathrm{M}-\mathrm{Me}^{+}\right)$: 352.035953 . Found: 352.035953 .

Diol 14:

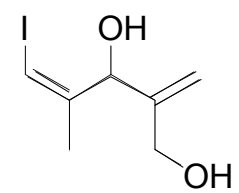

To a solution of $t \mathrm{BuLi}(13.8 \mathrm{~mL}, 1.7 \mathrm{M}$ - solution in pentane, $23.5 \mathrm{mmol})$ in $\mathrm{Et}_{2} \mathrm{O}(50$ $\mathrm{mL})$ at $-78{ }^{\circ} \mathrm{C}$ was added iodoalcohol $\mathbf{1 3}^{3}(1.39 \mathrm{~g}, 7.58 \mathrm{mmol})$ in $\mathrm{Et}_{2} \mathrm{O}(50 \mathrm{~mL})$ over a period of 30 minutes. To this mixture was added a solution of freshly prepared aldehyde $\mathbf{1 2}^{4}(990 \mathrm{mg}, 5.50 \mathrm{mmol})$ in $\mathrm{Et}_{2} \mathrm{O}(10 \mathrm{~mL})$. The mixture was stirred for 10 minutes. A solution of saturated aqueous $\mathrm{NH}_{4} \mathrm{Cl}(50 \mathrm{~mL})$ was added. The layers were separated and the aqueous layer was extracted with $\mathrm{CH}_{2} \mathrm{Cl}_{2}(2 \times 30 \mathrm{~mL})$. The combined organic layers were dried over $\mathrm{Na}_{2} \mathrm{SO}_{4}$, filtered, and concentrated in vacuo. At this point the material is sufficiently pure for silyl protection (see below). However, analytically pure diol could be obtained by purification by silica gel chromatography (3:2 hexanes:EtOAc) to give diol 14 as a yellow oil. Data for 14: $\mathrm{R}_{\mathrm{f}} 0.30\left(3: 2\right.$ hexanes:EtOAc); IR $3343(\mathrm{br}) \mathrm{cm}^{-1} ;{ }^{1} \mathrm{H}$ NMR $\left(\mathrm{CDCl}_{3}, 400 \mathrm{MHz}\right) \delta 6.13(\mathrm{~s}, 1 \mathrm{H}), 5.25(\mathrm{~m}, 3 \mathrm{H}), 4.16(\mathrm{~m}, 2 \mathrm{H}), 2.45(\mathrm{br} \mathrm{s}, 1 \mathrm{H}), 2.05$ (br s, $1 \mathrm{H}), 1.85(\mathrm{~s}, 3 \mathrm{H}) ;{ }^{13} \mathrm{C} \mathrm{NMR}\left(\mathrm{CDCl}_{3}, 125 \mathrm{MHz}\right) \delta 146.6,146.5,112.1,76.6,76.5$, 64.0, 18.7; HRMS (EI) Calculated for $\mathrm{C}_{7} \mathrm{H}_{11} \mathrm{O}_{2} \mathrm{I}\left(\mathrm{M}^{+}\right)$: 253.980382 . Found: 253.980689 .

Divinyl carbinol S2:

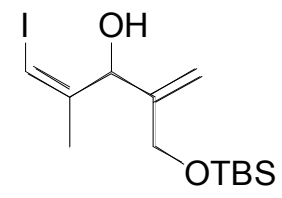

The crude diol 14 described above was dissolved in $\mathrm{CH}_{2} \mathrm{Cl}_{2}(70 \mathrm{~mL})$ at rt. To this mixture was added imidazole $(1.72 \mathrm{~g}, 25.3 \mathrm{mmol})$ and TBSCl $(1.53 \mathrm{~g}, 10.1 \mathrm{mmol})$. The mixture was allowed to stir for 30 minutes, upon which time saturated aqueous $\mathrm{NH}_{4} \mathrm{Cl}$ was added. The layers were separated and the organic layer was washed with saturated aqueous $\mathrm{NH}_{4} \mathrm{Cl}(2 \times 50 \mathrm{~mL})$. The combined aqueous layers were then extracted with 
$\mathrm{CH}_{2} \mathrm{Cl}_{2}(3 \times 50 \mathrm{~mL})$. The combined organic layers were dried over $\mathrm{Na}_{2} \mathrm{SO}_{4}$, filtered, and concentrated in vacuo. Purification by silica gel chromatography (3:2 hexanes:EtOAc) gave S2 $(826 \mathrm{mg}, 44 \%)$ as a clear oil. Data for S2: $\mathrm{R}_{\mathrm{f}} 0.33\left(6: 1\right.$ hexanes:Et $\left._{2} \mathrm{O}\right)$; IR 3424 (br) $\mathrm{cm}^{-1} ;{ }^{1} \mathrm{H}$ NMR $\left(\mathrm{CDCl}_{3}, 400 \mathrm{MHz}\right) \delta 6.10(\mathrm{~s}, 1 \mathrm{H}), 5.22(\mathrm{~m}, 1 \mathrm{H}), 5.17($ app s, 2H), $4.18(\mathrm{~m}, 2 \mathrm{H}), 2.60(\mathrm{br} \mathrm{s}, 1 \mathrm{H}), 1.86(\mathrm{~s}, 3 \mathrm{H}), 0.92(\mathrm{~s}, 9 \mathrm{H}), 0.10(\mathrm{~s}, 3 \mathrm{H}), 0.09(\mathrm{~s}, 3 \mathrm{H}) ;{ }^{13} \mathrm{C}$ NMR $\left(\mathrm{CDCl}_{3}, 100 \mathrm{MHz}\right) \delta 146.9,146.4,111.0,76.97,76.3,64.8,25.9,19.0,18.3$; HRMS (EI) Calculated for $\mathrm{C}_{13} \mathrm{H}_{25} \mathrm{O}_{2} \mathrm{SiILi}\left(\mathrm{M}+\mathrm{Li}^{+}\right)$: 375.082865. Found: 375.083680 . Anal. Calculated for $\mathrm{C}_{13} \mathrm{H}_{25} \mathrm{O}_{2} \mathrm{SiI}$ : C, 42.39\%; H, 6.79\%. Found: C, 43.07\%; H, 7.09\%.

Acetate 15:

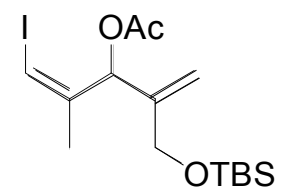

To a solution of divinyl carbinol $\mathbf{S 1}(5.0 \mathrm{~g}, 13.6 \mathrm{mmol})$ in $\mathrm{CH}_{2} \mathrm{Cl}_{2}(120 \mathrm{~mL})$ at $\mathrm{rt}$ was added sequentially DMAP (166 mg, $1.36 \mathrm{mmol}), \mathrm{Et}_{3} \mathrm{~N}(18.9 \mathrm{~mL}, 136 \mathrm{mmol})$, and $\mathrm{Ac}_{2} \mathrm{O}$ (2.57 mL, $27.2 \mathrm{mmol})$. The mixture was stirred for 2 hours upon which time it was diluted with $\mathrm{CH}_{2} \mathrm{Cl}_{2}(150 \mathrm{~mL})$ and a saturated solution of $\mathrm{NH}_{4} \mathrm{Cl}(200 \mathrm{~mL})$. The layers were separated and the organic layer was washed with additional $\mathrm{NH}_{4} \mathrm{Cl}$ solution $(200$ $\mathrm{mL})$. The combined aqueous layers were extracted with $\mathrm{CH}_{2} \mathrm{Cl}_{2}(3 \times 200 \mathrm{~mL})$. The organic layers were combined, dried over $\mathrm{MgSO}_{4}$, filtered and concentrated. Purification by silica gel chromatography $\left(7: 1\right.$ hexanes:Et $\left.{ }_{2} \mathrm{O}\right)$ gave acetate $15(5.47 \mathrm{~g}, 98 \%)$ as a clear liquid. Data for 15: $\mathrm{R}_{\mathrm{f}} 0.63$ (5:1 hexanes:Et $\left.2 \mathrm{O}\right)$; IR $1746 \mathrm{~cm}^{-1} ;{ }^{1} \mathrm{H} \mathrm{NMR}\left(\mathrm{CDCl}_{3}, 400\right.$ $\mathrm{MHz}) \delta 6.19(\mathrm{~s}, 1 \mathrm{H}), 6.05(\mathrm{~s}, 1 \mathrm{H}), 5.29(\mathrm{~s}, 1 \mathrm{H}), 5.11(\mathrm{~s}, 1 \mathrm{H}), 4.10(\mathrm{~m}, 2 \mathrm{H}), 2.07(\mathrm{~s}, 3 \mathrm{H})$, $1.77(\mathrm{~s}, 3 \mathrm{H}), 0.89(\mathrm{~s}, 9 \mathrm{H}), 0.04(\mathrm{~s}, 6 \mathrm{H}) ;{ }^{13} \mathrm{C} \mathrm{NMR}\left(\mathrm{CDCl}_{3}, 100 \mathrm{MHz}\right) \delta 169.1,143.9$, 143.0, 110.2, 78.3, 77.3, 62.8, 25.8, 20.7, 19.3, 18.2, -5.22, -5.25; HRMS (FAB) Calculated for $\mathrm{C}_{11} \mathrm{H}_{18} \mathrm{IO}_{3} \mathrm{Si}\left(\mathrm{M}-t \mathrm{Bu}^{+}\right)$: 353.007000. Found: 353.007680. Anal. Calculated for $\mathrm{C}_{11} \mathrm{H}_{18} \mathrm{IO}_{3} \mathrm{Si}$ : C, 43.90\%; H, 6.59\%. Found: C, 44.04\%; H, 6.83\%.

Eschenmoser-Claisen product S3:

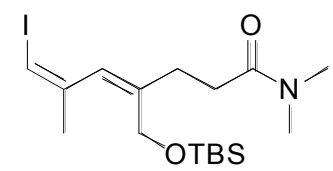

To a solution of divinylcarbinol $15(32 \mathrm{mg}, 0.087 \mathrm{mmol})$ in xylene $(1.75 \mathrm{~mL})$ was added $\mathrm{Me}_{2} \mathrm{NC}(\mathrm{OMe})_{2} \mathrm{Me}(190 \mu \mathrm{L}, 1.30 \mathrm{~mL})$. The mixture was heated to $110{ }^{\circ} \mathrm{C}$ for 3 hours. The reaction mixture was allowed to cool to $\mathrm{rt}$ and loaded directly onto a silica gel column (2:1 Et ${ }_{2} \mathrm{O}$ :hexanes) to give $\mathbf{S 3}(32 \mathrm{mg}, 83 \%)$ as a pale yellow oil. Data for $\mathbf{S 3}$ : $\mathbf{R}_{\mathrm{f}}$ 0.33 (2:1 Et $2 \mathrm{O}$ :hexanes); IR $1650 \mathrm{~cm}^{-1} ;{ }^{1} \mathrm{H} \mathrm{NMR}\left(\mathrm{CDCl}_{3}, 400 \mathrm{MHz}\right) \delta 6.02(\mathrm{~s}, 1 \mathrm{H}), 5.68$ $(\mathrm{s}, 1 \mathrm{H}), 4.14(\mathrm{~s}, 2 \mathrm{H}), 3.03(\mathrm{~s}, 3 \mathrm{H}), 2.95(\mathrm{~s}, 3 \mathrm{H}), 2.53(\operatorname{app~s}, 4 \mathrm{H}), 1.95(\mathrm{~s}, 3 \mathrm{H}), 0.88(\mathrm{~s}$, $9 \mathrm{H}), 0.042(\mathrm{~s}, 6 \mathrm{H}) ;{ }^{13} \mathrm{C} \mathrm{NMR}\left(\mathrm{CDCl}_{3}, 100 \mathrm{MHz}\right) \delta 172.6,144.6,141.4,128.0,77.7,62.0$, $37.4,35.5,32.5,30.0,25.9,24.8,18.3,-5.4$; HRMS (FAB) Calculated for $\mathrm{C}_{17} \mathrm{H}_{33} \mathrm{NO}_{2} \mathrm{SiI}$ $\left(\mathrm{M}+\mathrm{H}^{+}\right)$: 438.132535. Found: 438.132760. 
Carboxylic acid 17:

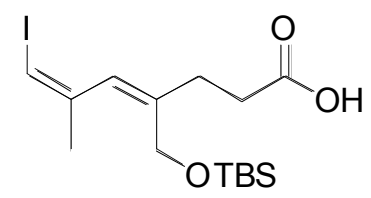

To a solution of $i \operatorname{Pr}_{2} \mathrm{NH}(2.17 \mathrm{~mL}, 15.5 \mathrm{mmol})$ in THF $(15 \mathrm{~mL})$ at $0{ }^{\circ} \mathrm{C}$ was added BuLi (2.5 M, $5.70 \mathrm{~mL}, 14.3 \mathrm{mmol})$. The mixture was stirred for 20 minutes, upon which time it was transferred via cannula to a solution of acetate $15(5.08 \mathrm{~g}, 12.4 \mathrm{mmol})$ in THF (235 $\mathrm{mL})$ at $-78{ }^{\circ} \mathrm{C}$. As soon as the transfer was complete, TMSCl $(3.16 \mathrm{~mL}, 24.8 \mathrm{mmol})$ was added and the mixture was stirred for $1 \mathrm{~h}$. The mixture was allowed to warm to $0{ }^{\circ} \mathrm{C}$ for $1 \mathrm{~h}$, then $\mathrm{rt}$ for $1 \mathrm{~h}$, and was finally heated to $55{ }^{\circ} \mathrm{C}$ for 3 hours. The mixture was then cooled to rt, diluted with $\mathrm{CH}_{2} \mathrm{Cl}_{2}(150 \mathrm{~mL})$, and a $1 \mathrm{M} \mathrm{HCl}$ solution $(150 \mathrm{~mL})$ was slowly added. The layers were separated and the organic phase was washed with $1 \mathrm{M} \mathrm{HCl}$ solution $(100 \mathrm{~mL})$. The combined aqueous layers were extracted with $\mathrm{CH}_{2} \mathrm{Cl}_{2}(2 \times 100$ $\mathrm{mL}$ ). The organic layers were combined, dried over $\mathrm{Na}_{2} \mathrm{SO}_{4}$, filtered, and concentrated in vacuo. Purification by silica gel chromatography $\left(5: 1\right.$ then $2: 1$ hexanes: $\left.\mathrm{Et}_{2} \mathrm{O}\right)$ gave silyl acetate $\mathbf{S 4}(1.93 \mathrm{~g}, 32 \%)$ as a clear liquid and carboxylic acid $\mathbf{1 7}(2.42 \mathrm{~g}, 48 \%)$ as a yellow oil which solidifies upon standing at $-20^{\circ} \mathrm{C}$.

Silyl acetate S4:

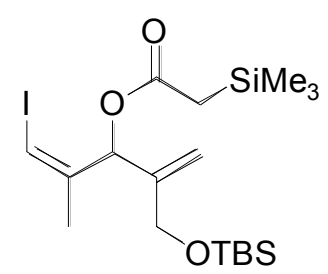

Data for S4: $\mathrm{R}_{\mathrm{f}} 0.74\left(5: 1\right.$ hexanes:Et $\left.{ }_{2} \mathrm{O}\right)$; IR $1728 \mathrm{~cm}^{-1} ;{ }^{1} \mathrm{H}$ NMR $\left(\mathrm{CDCl}_{3}, 500 \mathrm{MHz}\right) \delta$ $6.19(\mathrm{~s}, 1 \mathrm{H}), 6.07(\mathrm{~s}, 1 \mathrm{H}), 5.32(\mathrm{~s}, 1 \mathrm{H}), 5.15(\mathrm{~s}, 1 \mathrm{H}), 4.17(\mathrm{~d}, 1 \mathrm{H}, J=15 \mathrm{~Hz}), 4.06(\mathrm{~d}, 1 \mathrm{H}$, $J=15 \mathrm{~Hz}), 1.95(\mathrm{~s}, 2 \mathrm{H}), 1.80(\mathrm{~s}, 3 \mathrm{H}), 0.91(\mathrm{~s}, 9 \mathrm{H}), 0.14(\mathrm{~s}, 9 \mathrm{H}), 0.01(\mathrm{~s}, 6 \mathrm{H}) ;{ }^{13} \mathrm{C}$ NMR $\left(\mathrm{CDCl}_{3}, 125 \mathrm{MHz}\right) \delta 171.2,144.4,143.5,109.9,78.0,62.8,26.7,25.9,19.4,18.3,-1.3,-$ 5.4, -5.5; HRMS (FAB) Calculated for $\mathrm{C}_{18} \mathrm{H}_{35} \mathrm{IO}_{3} \mathrm{Si}_{2}\left(\mathrm{M}^{+}\right)$: 483.124779 . Found: 483.124240 .

Data for 17: $\mathrm{R}_{\mathrm{f}} 0.33(2: 1$ hexanes:Et $2 \mathrm{O})$; IR $1710 \mathrm{~cm}^{-1} ;{ }^{1} \mathrm{H}$ NMR $\left(\mathrm{CDCl}_{3}, 400 \mathrm{MHz}\right) \delta$ $6.05(\mathrm{~s}, 1 \mathrm{H}), 5.67(\mathrm{~s}, 1 \mathrm{H}), 4.14(\mathrm{~s}, 2 \mathrm{H}), 2.58(\mathrm{~m}, 4 \mathrm{H}), 1.94(\mathrm{~s}, 3 \mathrm{H}), 0.89(\mathrm{~s}, 9 \mathrm{H}), 0.06(\mathrm{~s}$, $6 \mathrm{H}) ;{ }^{13} \mathrm{C}$ NMR $\left(\mathrm{CDCl}_{3}, 100 \mathrm{MHz}\right) \delta 179.6,144.4,140.1,128.3,77.7,61.6,33.0,29.2$, 25.9, 24.8, 18.2, -5.3; HRMS (FAB) Calculated for $\mathrm{C}_{18} \mathrm{H}_{35} \mathrm{IO}_{3} \mathrm{Si}_{2}\left(\mathrm{M}+\mathrm{H}^{+}\right): 411.085250$. Found: 411.086320 . 
Conversion of silyl acetate $\mathbf{S} 4$ to acetate $\mathbf{1 5}$ :

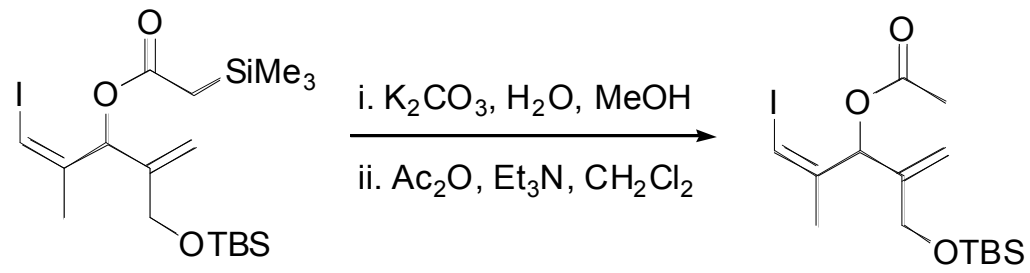

To a solution of silyl acetate $\mathbf{S} 4 \mathbf{~ ( 7 8 ~} \mathrm{mg}, 0.162 \mathrm{mmol})$ in $\mathrm{MeOH}(1.2 \mathrm{~mL})$ was added $\mathrm{H}_{2} \mathrm{O}$ $(0.4 \mathrm{~mL})$ (becomes cloudy) and $\mathrm{K}_{2} \mathrm{CO}_{3}(45 \mathrm{mg}, 0.324 \mathrm{mmol})$. The mixture was stirred for 30 minutes during which time the solution becomes homogeneous and TLC indicates disappearance of starting material. The mixture was diluted with EtOAc $(20 \mathrm{~mL})$ and a saturated solution of $\mathrm{NH}_{4} \mathrm{Cl}(20 \mathrm{~mL})$. The layers were separated and the organic layer was washed with additional $\mathrm{NH}_{4} \mathrm{Cl}$ solution. The combined aqueous layers were extracted with EtOAc $(3 \times 20 \mathrm{~mL})$. The organic layers were combined, dried over $\mathrm{MgSO}_{4}$, filtered and concentrated. The crude reaction material consisted of acetate $\mathbf{1 5}$ and divinyl carbinol $\mathbf{S 2}$ in ratios that varied with the reaction time. The crude material was then dissolved in $\mathrm{CH}_{2} \mathrm{Cl}_{2}(1.6 \mathrm{~mL})$ and treated sequentially with DMAP $(2 \mathrm{mg}, 0.016$ $\mathrm{mmol}), \mathrm{Et}_{3} \mathrm{~N}(225 \mathrm{uL}, 1.62 \mathrm{mmol})$, and $\mathrm{Ac}_{2} \mathrm{O}(31 \mathrm{uL}, 0.324 \mathrm{mmol})$. The mixture was stirred at $\mathrm{rt}$ for 1.5 hours (upon which time TLC indicated the presence of only acetate 15). The mixture was diluted with $\mathrm{CH}_{2} \mathrm{Cl}_{2}(20 \mathrm{~mL})$ and a saturated solution of $\mathrm{NH}_{4} \mathrm{Cl}$ $(20 \mathrm{~mL})$. The layers were separated and the organic layer was washed with additional $\mathrm{NH}_{4} \mathrm{Cl}$ solution. The combined aqueous layers were extracted with $\mathrm{CH}_{2} \mathrm{Cl}_{2}(3 \times 20 \mathrm{~mL})$. The organic layers were combined, dried over $\mathrm{MgSO}_{4}$, filtered and concentrated. Purification by silica gel chromatography $\left(7: 1\right.$ hexanes: $\left.\mathrm{Et}_{2} \mathrm{O}\right)$ gave acetate $\mathbf{1 5}(65 \mathrm{mg}$, $97 \%$ ) as a clear liquid.

Methyl ester 18:

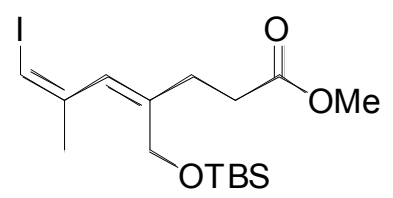

To a solution of acid $17(272 \mathrm{mg}, 0.663 \mathrm{mmol})$ in acetone $(7 \mathrm{~mL})$ was added $\mathrm{K}_{2} \mathrm{CO}_{3}(275$ $\mathrm{mg}, 1.99 \mathrm{mmol})$ and $\mathrm{MeI}(50 \mathrm{uL}, 0.80 \mathrm{mmol})$. The mixture was then heated to $55^{\circ} \mathrm{C}$ for 2 hours, cooled to rt, and diluted with $\mathrm{Et}_{2} \mathrm{O}(20 \mathrm{~mL})$ and a saturated solution of $\mathrm{NH}_{4} \mathrm{Cl}$ $(20 \mathrm{~mL})$. The layers were separated and the organic layer was washed with additional $\mathrm{NH}_{4} \mathrm{Cl}$ solution $(20 \mathrm{~mL})$. The combined aqueous layers were extracted with $\mathrm{Et}_{2} \mathrm{O}(2 \times 20$ $\mathrm{mL}$ ). The organic layers were combined, dried over $\mathrm{MgSO}_{4}$, filtered through a short pad of silica and concentrated to give methyl ester $18(281 \mathrm{mg}, 100 \%)$ as a pale yellow liquid. Data for 18: $\mathrm{R}_{\mathrm{f}} 0.40\left(10: 1\right.$ hexanes: $\left.\mathrm{Et}_{2} \mathrm{O}\right)$; IR $1740 \mathrm{~cm}^{-1} ;{ }^{1} \mathrm{H} \mathrm{NMR}\left(\mathrm{CDCl}_{3}, 400 \mathrm{MHz}\right) \delta$ $6.03(\mathrm{~s}, 1 \mathrm{H}), 5.65(\mathrm{~s}, 1 \mathrm{H}), 4.12(\mathrm{~s}, 2 \mathrm{H}), 3.65(\mathrm{~s}, 3 \mathrm{H}), 2.56(\mathrm{~m}, 4 \mathrm{H}), 1.94(\mathrm{~s}, 3 \mathrm{H}), 0.88(\mathrm{~s}$, 9H), $0.05(\mathrm{~s}, 6 \mathrm{H}) ;{ }^{13} \mathrm{C} \mathrm{NMR}\left(\mathrm{CDCl}_{3}, 100 \mathrm{MHz}\right) \delta 173.6,144.5,140.6,128.0,77.6,61.6$, 51.6, 32.9, 29.3, 25.8, 24.8, 18.2, -5.3; HRMS (FAB) Calculated for $\mathrm{C}_{16} \mathrm{H}_{29} \mathrm{IO}_{3} \mathrm{SiLi}$ $\left(\mathrm{M}+\mathrm{Li}^{+}\right): 431.109080$. Found: 431.109930 . 
Bromide S5:

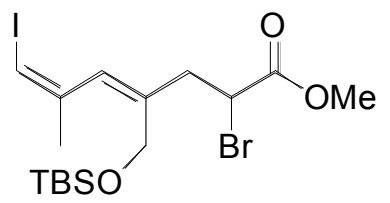

To a solution of methyl ester $18(52 \mathrm{mg}, 0.12 \mathrm{mmol})$ in THF $(1 \mathrm{~mL})$ at $-78^{\circ} \mathrm{C}$ was added TMSCl $(23 \mathrm{uL}, 0.18 \mathrm{mmol})$ and then LDA prepared as above (146 uL, 1M, $0.15 \mathrm{mmol})$. The mixture was stirred at $-78{ }^{\circ} \mathrm{C}$ for $1 \mathrm{~h}$ upon which time a solution of NBS (44 mg, $0.25 \mathrm{mmol})$ in THF $(1 \mathrm{~mL})$ was added via cannula. The mixture was stirred for 30 minutes and then diluted with $\mathrm{Et}_{2} \mathrm{O}(10 \mathrm{~mL})$ and a saturated solution of $\mathrm{NH}_{4} \mathrm{Cl}(10 \mathrm{~mL})$. The layers were separated and the organic layer was washed with additional $\mathrm{NH}_{4} \mathrm{Cl}$ solution $(10 \mathrm{~mL})$. The combined aqueous layers were extracted with $\mathrm{Et}_{2} \mathrm{O}(2 \times 10 \mathrm{~mL})$. The organic layers were combined, dried over $\mathrm{Na}_{2} \mathrm{SO}_{4}$, filtered, and concentrated. Purification by silica gel chromatography (25:1 hexanes: $\left.\mathrm{Et}_{2} \mathrm{O}\right)$ gave bromide $\mathbf{S 5}(48 \mathrm{mg}$, $77 \%)$ as a pale yellow liquid. Data for S5: $\mathrm{R}_{\mathrm{f}} 0.34(20: 1$ hexanes:Et $2 \mathrm{O})$; IR $1745 \mathrm{~cm}^{-1}$; ${ }^{1} \mathrm{H} \mathrm{NMR}\left(\mathrm{CDCl}_{3}, 400 \mathrm{MHz}\right) \delta 6.08(\mathrm{~s}, 1 \mathrm{H}), 5.73(\mathrm{~s}, 1 \mathrm{H}), 4.56(\mathrm{dd}, 1 \mathrm{H}, J=8,7 \mathrm{~Hz}), 4.14$ (m, 2H), $3.77(\mathrm{~s}, 3 \mathrm{H}), 3.04(\mathrm{dd}, 1 \mathrm{H}, J=14,8 \mathrm{~Hz}), 2.82(\mathrm{dd}, 1 \mathrm{H}, J=14,7 \mathrm{~Hz}), 1.91(\mathrm{~s}$, $3 \mathrm{H}), 0.91$ (s, 9H), $0.04($ app s, $6 \mathrm{H}) ;{ }^{13} \mathrm{C} \mathrm{NMR}\left(\mathrm{CDCl}_{3}, 100 \mathrm{MHz}\right) \delta 170.2,144.0,136.9$, 131.2, 77.8, 61.6, 52.9, 43.2, 39.8, 25.8, 24.7, 18.1, -5.4; HRMS (FAB) Calculated for $\mathrm{C}_{16} \mathrm{H}_{29} \mathrm{IO}_{3} \mathrm{SiBr}\left(\mathrm{M}+\mathrm{H}^{+}\right): 505.009365$. Found: 505.010440. Anal. Calculated for $\mathrm{C}_{16} \mathrm{H}_{28} \mathrm{IO}_{3} \mathrm{SiBr}$ : C, 38.18\%; H, 5.61\%. Found: $\mathrm{C}, 38.56 \%$; H, 5.87\%.

Tetrahydrofuranyl ester 19:

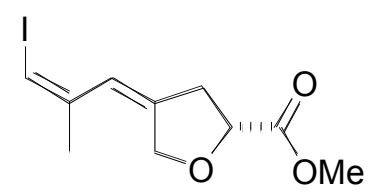

A solution of bromide $\mathbf{S 5}(1.01 \mathrm{~g}, 2.00 \mathrm{mmol})$ in DMF $(67 \mathrm{~mL})$ was heated to $100{ }^{\circ} \mathrm{C}$ for $30 \mathrm{~min}$. The solution was cooled to $0{ }^{\circ} \mathrm{C}$ and diluted with $\mathrm{Et}_{2} \mathrm{O}(100 \mathrm{~mL})$. A saturated solution of $\mathrm{NH}_{4} \mathrm{Cl}(100 \mathrm{~mL})$ was added. The layers were separated and the organic layer was washed with additional $\mathrm{NH}_{4} \mathrm{Cl}$ solution $(100 \mathrm{~mL})$. The combined aqueous layers were extracted with $\mathrm{Et}_{2} \mathrm{O}(2 \times 100 \mathrm{~mL})$. The organic layers were combined, dried over $\mathrm{MgSO}_{4}$, filtered, and concentrated. Purification by silica gel chromatography (2:1 hexanes: $\left.\mathrm{Et}_{2} \mathrm{O}\right)$ gave tetrahydrofuranyl ester $\mathbf{1 9}(584 \mathrm{mg}, 95 \%)$ as an orange liquid. Data for 19: $\mathrm{R}_{\mathrm{f}} 0.36\left(2: 1\right.$ hexanes: $\left.\mathrm{Et}_{2} \mathrm{O}\right) ; \mathrm{IR} 1746 \mathrm{~cm}^{-1} ;{ }^{1} \mathrm{H}$ NMR $\left(\mathrm{CDCl}_{3}, 500 \mathrm{MHz}\right) \delta 6.25$ (s, 1H), $6.01(\mathrm{~s}, 1 \mathrm{H}), 4.73(\mathrm{~d}, 1 \mathrm{H}, J=14 \mathrm{~Hz}), 4.55(\mathrm{~m}, 2 \mathrm{H}), 3.72(\mathrm{~s}, 3 \mathrm{H}), 3.02(\mathrm{~m}, 1 \mathrm{H})$, $2.82(\mathrm{~m}, 1 \mathrm{H}), 1.95(\mathrm{~s}, 3 \mathrm{H}) ;{ }^{13} \mathrm{C} \mathrm{NMR}\left(\mathrm{CDCl}_{3}, 125 \mathrm{MHz}\right) \delta 172.4,141.5,141.4,123.7$, 78.9, 75.5, 69.3, 52.1, 38.4, 22.8; HRMS (EI) Calculated for $\mathrm{C}_{10} \mathrm{H}_{13} \mathrm{IO}_{3}\left(\mathrm{M}^{+}\right)$: 307.990946. Found: 307.991427. 
Tetrahydrofuranyl acid 20:

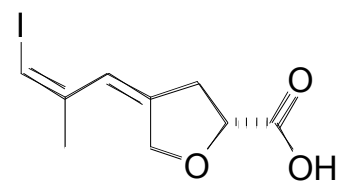

Tetrahydrofuranyl ester $19(171 \mathrm{mg}, 0.555 \mathrm{mmol})$ was dissolved in $\mathrm{MeOH}(5.6 \mathrm{~mL})$ at $\mathrm{rt}$ and treated with a $2 \mathrm{M} \mathrm{NaOH}$ solution $(833 \mathrm{uL}, 1.67 \mathrm{mmol})$. The mixture was stirred for 30 minutes upon which time it was diluted with $\mathrm{CH}_{2} \mathrm{Cl}_{2}(20 \mathrm{~mL})$ and a $0.5 \mathrm{M} \mathrm{HCl}$ solution was added $(20 \mathrm{~mL})$. The layers were separated and the organic layer was washed with additional $0.5 \mathrm{M} \mathrm{HCl}$ solution $(20 \mathrm{~mL})$. The combined aqueous layers were extracted with $\mathrm{CH}_{2} \mathrm{Cl}_{2}(3 \times 20 \mathrm{~mL})$. The organic layers were combined, dried over $\mathrm{MgSO}_{4}$, filtered, and concentrated to give 20 of sufficient purity for further reactions. Further purification by silica gel chromatography $\left(50: 1: 1 \mathrm{CH}_{2} \mathrm{Cl}_{2}: \mathrm{MeOH}: \mathrm{HOAc}\right)$ gave 20 (155 mg, 95\%) as an analytically pure white solid. Data for 20: $\mathrm{R}_{\mathrm{f}} 0.21$ (50:1:1 $\mathrm{CH}_{2} \mathrm{Cl}_{2}$ :MeOH:HOAc); mp $91{ }^{\circ} \mathrm{C}$; IR $1729 \mathrm{~cm}^{-1}$; ${ }^{1} \mathrm{H}$ NMR $\left(\mathrm{CDCl}_{3}, 500 \mathrm{MHz}\right) \delta 11.19$ (br s, 1H), $6.29(\mathrm{~s}, 1 \mathrm{H}), 6.06(\mathrm{~s}, 1 \mathrm{H}), 4.77(\mathrm{~d}, 1 \mathrm{H}, J=14 \mathrm{~Hz}), 4.64(\mathrm{~m}, 2 \mathrm{H}), 3.11(\mathrm{~m}, 1 \mathrm{H})$, $2.91(\mathrm{~m}, 1 \mathrm{H}), 1.97(\mathrm{~s}, 3 \mathrm{H}) ;{ }^{13} \mathrm{C} \mathrm{NMR}\left(\mathrm{CDCl}_{3}, 125 \mathrm{MHz}\right) \delta 177.7,141.4,140.7,124.1$, 79.3, 75.2, 69.5, 38.3, 22.9; HRMS (EI) Calculated for $\mathrm{C}_{9} \mathrm{H}_{11} \mathrm{IO}_{3}\left(\mathrm{M}^{+}\right)$: 293.975296. Found: 293.974693; Anal. Calculated for $\mathrm{C}_{9} \mathrm{H}_{11} \mathrm{IO}_{3}$ : C, 36.73\%; H, 3.74\%. Found: C, $37.04 \%$; H, 3.88\%.

a-Pyrone 23:

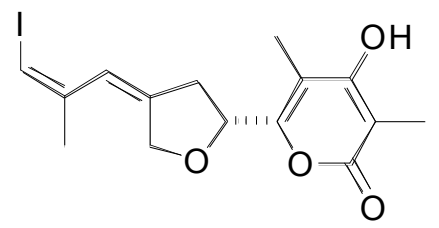

To a solution of acid 23 (129 mg, $0.438 \mathrm{mmol})$ in THF (1 mL) at rt was added carbonyl diimidazole ( $85 \mathrm{mg}, 0.53 \mathrm{mmol}$ ). The mixture was stirred for 1.5 hours upon which time it was diluted with $\mathrm{CH}_{2} \mathrm{Cl}_{2}(10 \mathrm{~mL})$ and $\mathrm{H}_{2} \mathrm{O}(10 \mathrm{~mL})$. The layers were separated and the organic layer was washed with $\mathrm{H}_{2} \mathrm{O}(10 \mathrm{~mL})$. The combined aqueous layers were then extracted with $\mathrm{CH}_{2} \mathrm{Cl}_{2}(2 \times 10 \mathrm{~mL})$. The organic layers were combined, dried over $\mathrm{MgSO}_{4}$, filtered, and concentrated to give the crude acyl imidazole sufficiently pure for the next reaction.

To a solution of $\mathrm{NaH}$ (35 mg, $60 \%$ disp. in mineral oil, $0.88 \mathrm{mmol})$ in THF ( $3 \mathrm{~mL})$ at 0 ${ }^{\circ} \mathrm{C}$ was added ketoester $22(126 \mathrm{mg}, 0.876 \mathrm{mmol})$. The mixture stirred for 5 minutes and then cooled to $-78{ }^{\circ} \mathrm{C}$. BuLi $(0.35 \mathrm{~mL}, 2.5 \mathrm{M}, 0.88 \mathrm{mmol})$ was added and the mixture was stirred for $30 \mathrm{~min}$. The mixture was warmed to $0{ }^{\circ} \mathrm{C}$ for 10 minutes and then cooled to $-78{ }^{\circ} \mathrm{C}$. A solution of acylimidazole (from above) in THF $(2.5 \mathrm{~mL})$ was added via cannula. The mixture was stirred for 2 hours at $-78^{\circ} \mathrm{C}$, and then a $0.5 \mathrm{M} \mathrm{HCl}$ solution (5 $\mathrm{mL})$ was added. The mixture was warmed to $\mathrm{rt}$, diluted with EtOAc $(5 \mathrm{~mL})$, and the layers were separated. The organic layer was washed with additional $0.5 \mathrm{M} \mathrm{HCl}$ solution $(5 \mathrm{~mL})$. The combined aqueous layers were extracted with EtOAc $(2 \times 5 \mathrm{~mL})$, dried over 
$\mathrm{MgSO}_{4}$, filtered, and concentrated. Purification by silica gel chromatography (5:1 hexanes:EtOAc) gave a mixture of diastereomeric tricarbonyl compounds (153 mg, 83\%) free of any remaining starting material, and sufficiently pure for the next step.

The tricarbonyl compound (from above) was dissolved in $\mathrm{PhH}(4 \mathrm{~mL})$ at $\mathrm{rt}$. DBU (65 uL, $0.44 \mathrm{mmol}$ ) was added and the mixture was heated to $80{ }^{\circ} \mathrm{C}$ for 3 hours. The $\mathrm{PhH}$ was removed on a rotary evaporator and the crude residue was purified by silica gel chromatography (50:1:1 $\left.\mathrm{CH}_{2} \mathrm{Cl}_{2}: \mathrm{MeOH}: \mathrm{HOAc}\right)$ to give $\mathbf{2 3}$ (99 mg, 70\%). Data for 23: $\mathrm{R}_{\mathrm{f}} 0.26$ (50:1:1 $\left.\quad \mathrm{CH}_{2} \mathrm{Cl}_{2}: \mathrm{MeOH}: \mathrm{HOAc}\right) ; \mathrm{mp} 148{ }^{\circ} \mathrm{C}$ (dec.); IR 1687, 1664, $1213 \mathrm{~cm}^{-1} ;{ }^{1} \mathrm{H}$ NMR $\left(\mathrm{CDCl}_{3}, 500 \mathrm{MHz}\right) \delta 6.29(\mathrm{~s}, 1 \mathrm{H}), 6.13(\mathrm{br} \mathrm{s}, 1 \mathrm{H}), 6.05(\mathrm{~s}, 1 \mathrm{H}), 4.98(\mathrm{app} \mathrm{t}, 1 \mathrm{H}, J$ $=8 \mathrm{~Hz}), 4.81(\mathrm{~d}, 1 \mathrm{H}, J=14 \mathrm{~Hz}), 4.57(\mathrm{~d}, 1 \mathrm{H}, J=14 \mathrm{~Hz}), 3.07(\mathrm{dd}, 1 \mathrm{H}, J=17,7 \mathrm{~Hz})$, $2.90(\mathrm{dd}, 1 \mathrm{H}, J=17,7 \mathrm{~Hz}), 2.06(\mathrm{~s}, 3 \mathrm{H}), 2.01(\mathrm{~s}, 3 \mathrm{H}), 1.97(\mathrm{~s}, 3 \mathrm{H}) ;{ }^{13} \mathrm{C} \mathrm{NMR}\left(\mathrm{CDCl}_{3}\right.$, $125 \mathrm{MHz}) \delta 164.5,163.2,154.3,142.9,141.7,123.6,108.7,100.1,78.8,73.5,69.7,38.1$, 23.1, 9.2, 8.5; HRMS (FAB) Calculated for $\mathrm{C}_{15} \mathrm{H}_{18} \mathrm{IO}_{4}\left(\mathrm{M}^{+}\right)$: 389.024986. Found: 389.025160 .

$\gamma$-Pyrone 10:

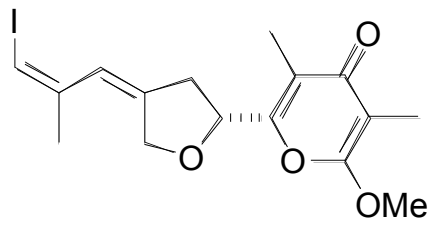

To a suspension of $\alpha$-pyrone 23 (226 mg, $0.584 \mathrm{mmol})$ in $\mathrm{CH}_{2} \mathrm{Cl}_{2}(6 \mathrm{~mL})$ at $\mathrm{rt}$ was added methyl fluorosulfonate ( $460 \mathrm{uL}, 5.84 \mathrm{mmol})$. The mixture was stirred for 3 hours during which time the solution cleared. The reaction vessel was cooled to $0{ }^{\circ} \mathrm{C}$ and the volatile materials were removed in vacuo. The residue was diluted with $\mathrm{CH}_{2} \mathrm{Cl}_{2}(10 \mathrm{~mL})$ and washed with $1 \mathrm{M} \mathrm{NaOH}$ solution $(2 \times 15 \mathrm{~mL})$. The combined aqueous layers were extracted with $\mathrm{CH}_{2} \mathrm{Cl}_{2}(3 \times 15 \mathrm{~mL})$. The organic layers were combined, dried over $\mathrm{MgSO}_{4}$, filtered, and concentrated. Purification by silica gel chromatography (1:1 hexanes:EtOAc) gave $\mathbf{1 0}(153 \mathrm{mg}, 65 \%)$ as a yellow solid. Data for 10: $\mathrm{R}_{\mathrm{f}} 0.25(1: 1$ hexanes:EtOAc); IR 1665, $1598 \mathrm{~cm}^{-1}$; ${ }^{1} \mathrm{H}$ NMR $\left(\mathrm{CDCl}_{3}, 400 \mathrm{MHz}\right) \delta 6.37(\mathrm{~s}, 1 \mathrm{H}), 6.09$ (s, 1H), $5.15(\mathrm{~m}, 1 \mathrm{H}), 4.76(\mathrm{~d}, 1 \mathrm{H}, J=19 \mathrm{~Hz}), 4.65(\mathrm{~d}, 1 \mathrm{H}, J=19 \mathrm{~Hz}), 3.92(\mathrm{~s}, 3 \mathrm{H}), 3.05$ $(\mathrm{m}, 1 \mathrm{H}), 2.95(\mathrm{~m}, 1 \mathrm{H}), 2.03(\mathrm{~s}, 3 \mathrm{H}), 2.02(\mathrm{~s}, 3 \mathrm{H}), 1.84(\mathrm{~s}, 3 \mathrm{H}) ;{ }^{13} \mathrm{C} \mathrm{NMR}\left(\mathrm{CDCl}_{3}, 100\right.$ MHz) $\delta 180.5,162.1,154.6,143.0,141.3,123.7,120.3,100.0,79.3,73.5,69.7,55.4$, 38.2, 23.0, 9.4, 6.9; HRMS (FAB) Calculated for $\mathrm{C}_{16} \mathrm{H}_{20} \mathrm{IO}_{4}\left(\mathrm{M}+\mathrm{H}^{+}\right)$: 403.040636. Found: 403.041360 .

Preparative resolution of $\mathbf{1 0}$ :

$\gamma$-Pyrone 10 was separated on a Chiralcel OD-RH semi-prep column (Particle Size $=5 \mu$, Internal Diameter $=10 \mathrm{~mm}$, Length $=250 \mathrm{~mm}$ ). The eluent was a $1: 1$ mixture of $\mathrm{MeCN}: \mathrm{H}_{2} \mathrm{O}(2.5 \mathrm{~mL} / \mathrm{min})$. The detector was set to $254 \mathrm{~nm}$, and approximately $5 \mathrm{mg}$ of racemic 10 were injected per run. The data trace below is representative. 
The two fractions were concentrated. Peak $1=(+)-S-10 . \quad[\alpha]^{25}{ }_{\mathrm{D}}=+140^{\circ}(c=0.5$, $\left.\mathrm{CH}_{2} \mathrm{Cl}_{2}\right)$. Peak $2=(-)-R-10 .[\alpha]^{25} \mathrm{D}=-159^{\circ}\left(c=1.0, \mathrm{CH}_{2} \mathrm{Cl}_{2}\right)$.

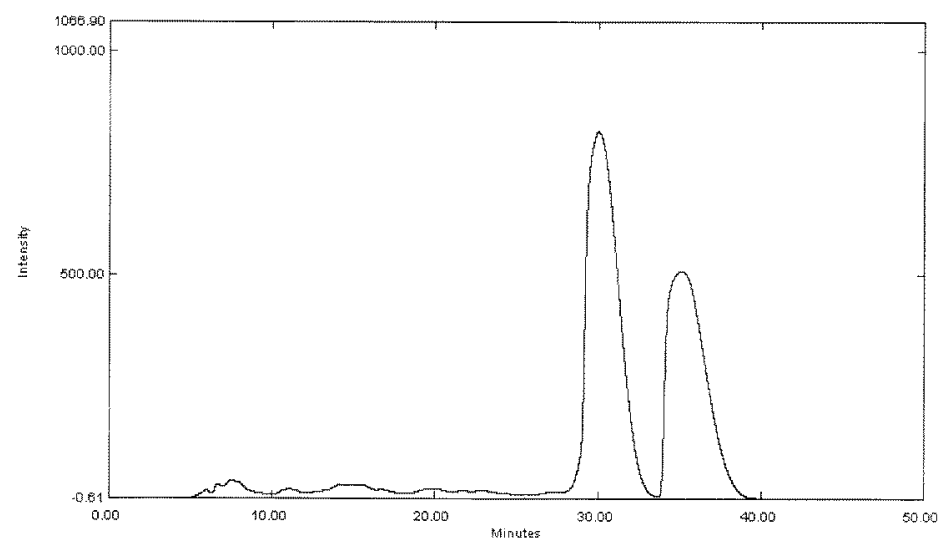

Enantiomerically pure (-)-1 and (+)-2:

To a solution of $(-)-\mathbf{1 0}(21 \mathrm{mg}, 0.052 \mathrm{mmol})$ and stannane $9(29 \mathrm{mg}, 0.078 \mathrm{mmol})$ in DMF $(1 \mathrm{~mL})$ at $\mathrm{rt}$ were added $\mathrm{CsF}(16 \mathrm{mg}, 0.10 \mathrm{mmol}), \mathrm{CuI}(2 \mathrm{mg}, 0.01 \mathrm{mmol})$ and $\mathrm{Pd}\left(\mathrm{Ph}_{3} \mathrm{P}\right)_{4}(6 \mathrm{mg}, 0.005 \mathrm{mmol})$. The mixture was heated to $45{ }^{\circ} \mathrm{C}$ for 3 hours. The mixture was cooled to rt, diluted with EtOAc $(15 \mathrm{~mL})$, and the organic layer was washed with a saturated $\mathrm{NH}_{4} \mathrm{Cl}$ solution $(3 \mathrm{x} 10 \mathrm{~mL})$. The combined aqueous layers were extracted with EtOAc ( 3 x $15 \mathrm{~mL})$. The organic layers were combined, dried over $\mathrm{MgSO}_{4}$, filtered, and concentrated. Purification by silica gel chromatography $(1: 1$ hexanes:EtOAc) gave $22 \mathrm{mg}$ of a 3:1 mixture of $1(67 \%)$ and $2(22 \%)$. The mixture was separated by HPLC according to the conditions reported by the isolationists ${ }^{5}$ to afford $\mathbf{1}$ and $\mathbf{2}$ as pale yellow solids. The enantiomeric excess was determined using chiral HPLC on an analytical Chiralcel OD column $(\mathrm{I} . \mathrm{D}=4.6 \mathrm{~mm}$, length $=250 \mathrm{~mm})$.

(-)-SNF4435 C (-)-(1): 90:10 hexanes:iPrOH (1.0 $\mathrm{mL} / \mathrm{min})$, minor isomer $18.7 \mathrm{~min}$, major isomer $21.3 \mathrm{~min}$ : $>99 \%$ ee. See data traces below.

(+)-SNF4435 D (+)-(2): 85:15 hexanes: $i \operatorname{PrOH}(1.0 \mathrm{~mL} / \mathrm{min})$, minor isomer $9.7 \mathrm{~min}$, major isomer 13.6 min: $99 \%$ ee. See data traces below.

Data for SNF4435 C (1): $\mathrm{R}_{\mathrm{f}} 0.28\left(1: 1\right.$ hexanes:EtOAc); $[\alpha]_{\mathrm{D}}=-100^{\circ}\left(c=1.0, \mathrm{CHCl}_{3}\right)$; IR 2952, 1665, 1598, 1517, $1346 \mathrm{~cm}^{-1} ;{ }^{1} \mathrm{H} \mathrm{NMR}\left(\mathrm{CDCl}_{3}, 400 \mathrm{MHz}\right) \delta 8.20(\mathrm{~d}, 2 \mathrm{H}, J=9$ $\mathrm{Hz}), 7.54(\mathrm{~s}, 2 \mathrm{H}, J=9 \mathrm{~Hz}), 5.58(\mathrm{~s}, 1 \mathrm{H}), 4.94(\mathrm{~s}, 1 \mathrm{H}), 4.76(\operatorname{app~t}, 1 \mathrm{H}, J=8 \mathrm{~Hz}), 4.32(\mathrm{~d}$, $1 \mathrm{H}, J=10 \mathrm{~Hz}), 3.96(\mathrm{~m}, 4 \mathrm{H}), 2.84(\mathrm{~s}, 1 \mathrm{H}), 2.43(\operatorname{app~d}, 2 \mathrm{H}, J=8 \mathrm{~Hz}), 1.89(\mathrm{~s}, 3 \mathrm{H}), 1.84$ $(\mathrm{s}, 3 \mathrm{H}), 1.74(\mathrm{~s}, 3 \mathrm{H}), 1.74(\mathrm{~s}, 3 \mathrm{H}), 1.72(\mathrm{~s}, 3 \mathrm{H}), 1.30(\mathrm{~s}, 3 \mathrm{H}) ;{ }^{13} \mathrm{C} \mathrm{NMR}\left(\mathrm{CDCl}_{3}, 125\right.$ $\mathrm{MHz}) \delta 180.6,162.0,155.0,146.8,145.1,131.0,130.4,129.1,123.7,123.6,122.0$, 119.6, 100.2, 73.5, 70.5, 63.6, 55.5, 51.8, 51.0, 46.3, 42.9, 30.4, 23.0, 22.2, 9.4, 6.9; HRMS (FAB) Calculated for $\mathrm{C}_{28} \mathrm{H}_{31} \mathrm{NO}_{6} \mathrm{Li}\left(\mathrm{M}+\mathrm{Li}^{+}\right)$: 484.231143. Found: 484.230620 . 
Data for SNF4435 D (2): $\mathrm{R}_{\mathrm{f}} 0.28$ (1:1 hexanes:EtOAc); $[\alpha]_{\mathrm{D}}=+26^{\circ}\left(c=1.0, \mathrm{CHCl}_{3}\right)$; IR 2951, 1667, 1599, 1518, $1346 \mathrm{~cm}^{-1} ;{ }^{1} \mathrm{H}$ NMR $\left(\mathrm{CDCl}_{3}, 400 \mathrm{MHz}\right) \delta 8.15(\mathrm{~d}, 2 \mathrm{H}, J=9$ $\mathrm{Hz}), 8.47,(\mathrm{~d}, 2 \mathrm{H}, J=9 \mathrm{~Hz}), 5.69$ (s, 1H), $4.94(\mathrm{dd}, 1 \mathrm{H}, J=9,7 \mathrm{~Hz}), 4.88(\mathrm{~s}, 1 \mathrm{H}), 4.18$ (d, $1 \mathrm{H}, J=9 \mathrm{~Hz}), 3.83(\mathrm{~d}, 1 \mathrm{H}, J=9 \mathrm{~Hz}), 3.74(\mathrm{~s}, 1 \mathrm{H}), 3.53(\mathrm{~s}, 3 \mathrm{H}), 2.73(\mathrm{~s}, 1 \mathrm{H}), 2.48$ (dd, $1 \mathrm{H}, J=13,7 \mathrm{~Hz}$ ), 2.28 (dd, $1 \mathrm{H}, J=13,9 \mathrm{~Hz}), 1.97$ (s, 3H), 1.83 (s, 3H), 1.79 (s, $3 \mathrm{H}), 1.73(\mathrm{~s}, 3 \mathrm{H}), 1.30(\mathrm{~s}, 3 \mathrm{H}) ;{ }^{13} \mathrm{C}$ NMR $\left(\mathrm{CDCl}_{3}, 125 \mathrm{MHz}\right) \delta 180.5,161.9,154.9$, 146.8, 144.0, 131.3, 131.2, 129.9, 124.4, 123.2, 121.8, 119.7, 99.9, 72.5, 70.6, 61.0, 55.2, 54.8, 51.1, 45.4, 43.0, 30.7, 22.5, 22.2, 9.5, 6.8; MS (FAB) Calculated for $\mathrm{C}_{28} \mathrm{H}_{32} \mathrm{NO}_{6}$ $\left(\mathrm{M}+\mathrm{H}^{+}\right)$: 478.222963. Found: 478.222190 .

\section{Racemic - SNF4435 C}

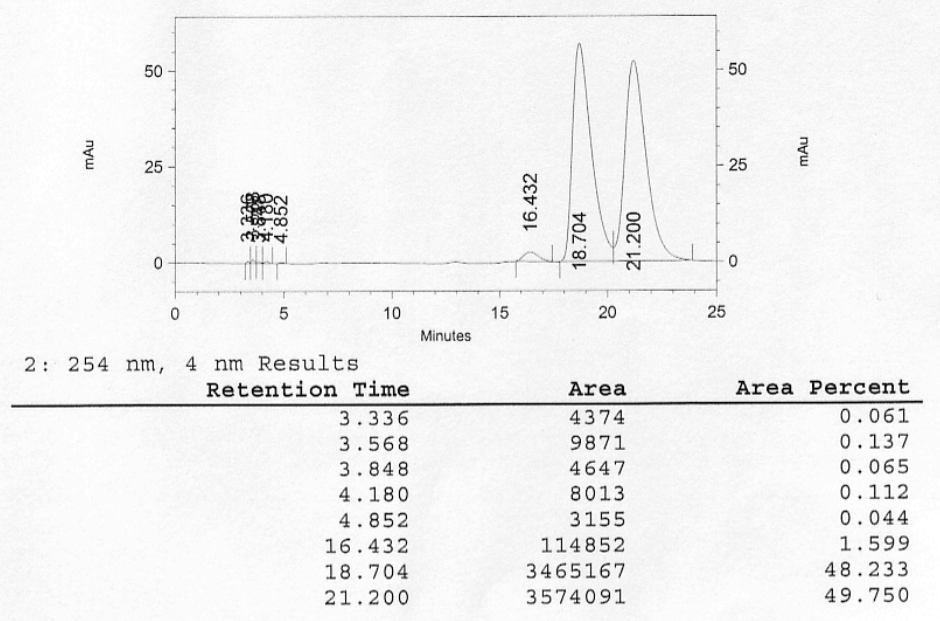

\section{(-)-SNF4435 C}

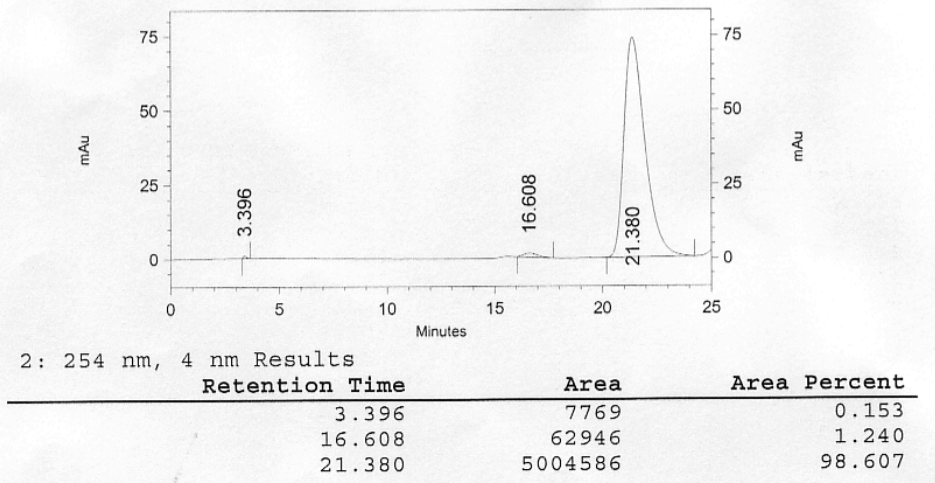




\section{Racemic - SNF4435 D}

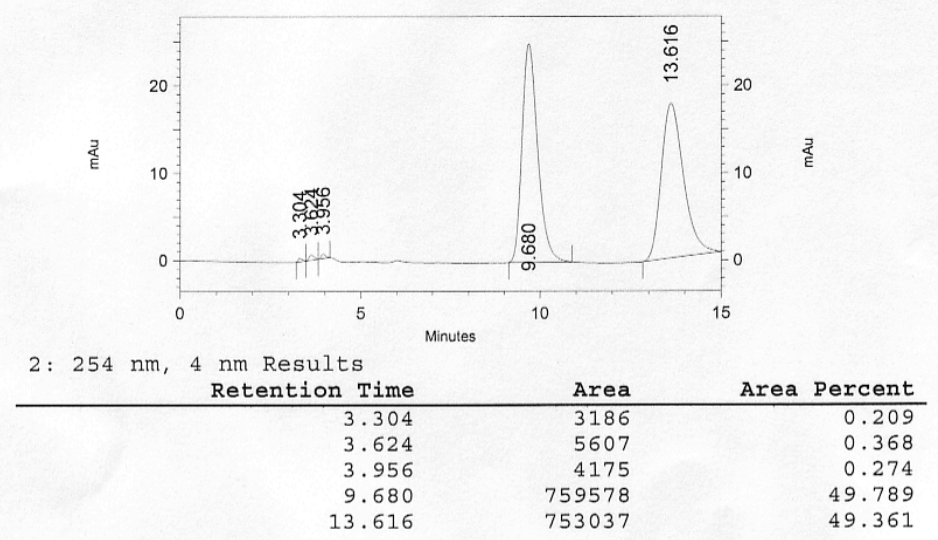

\section{(+)-SNF4435 D}

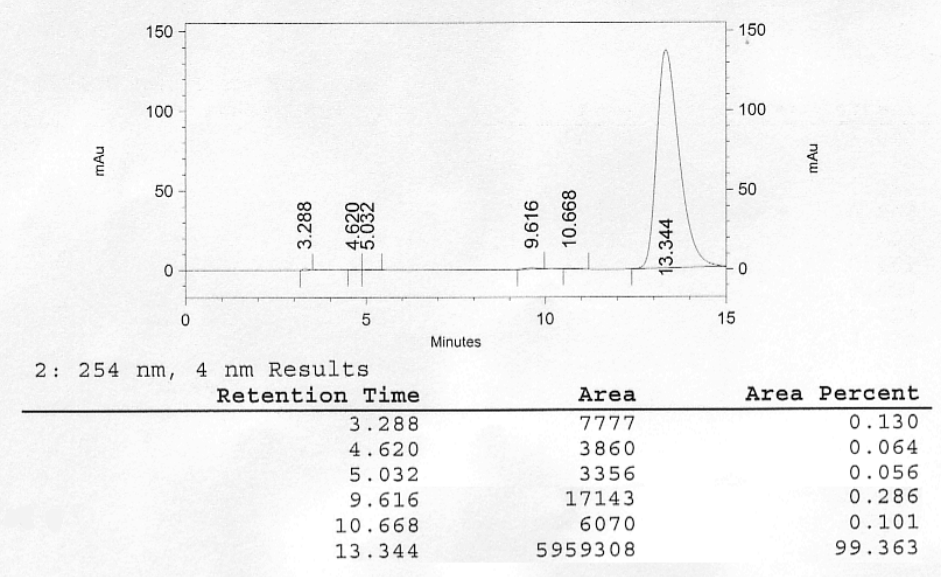




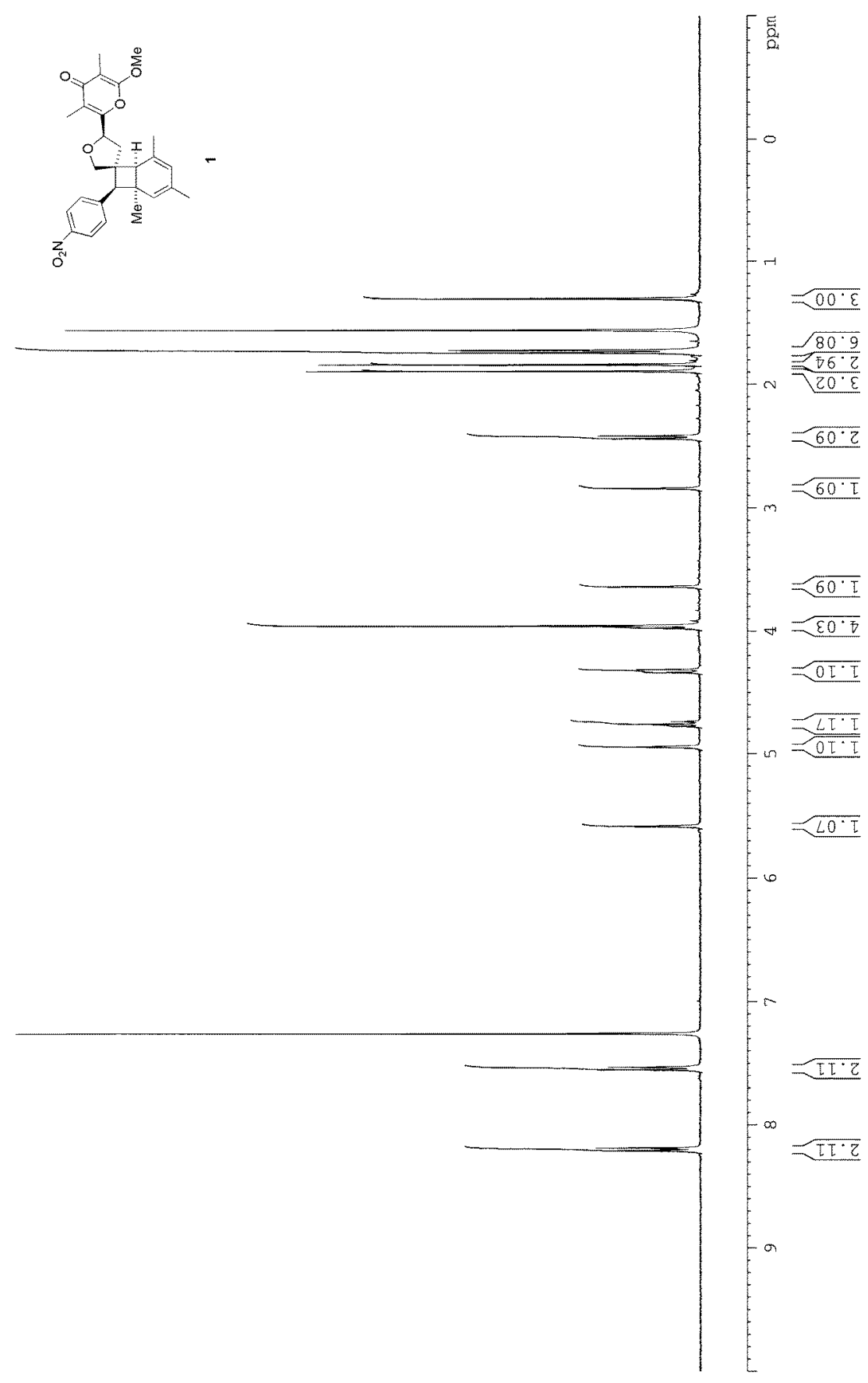




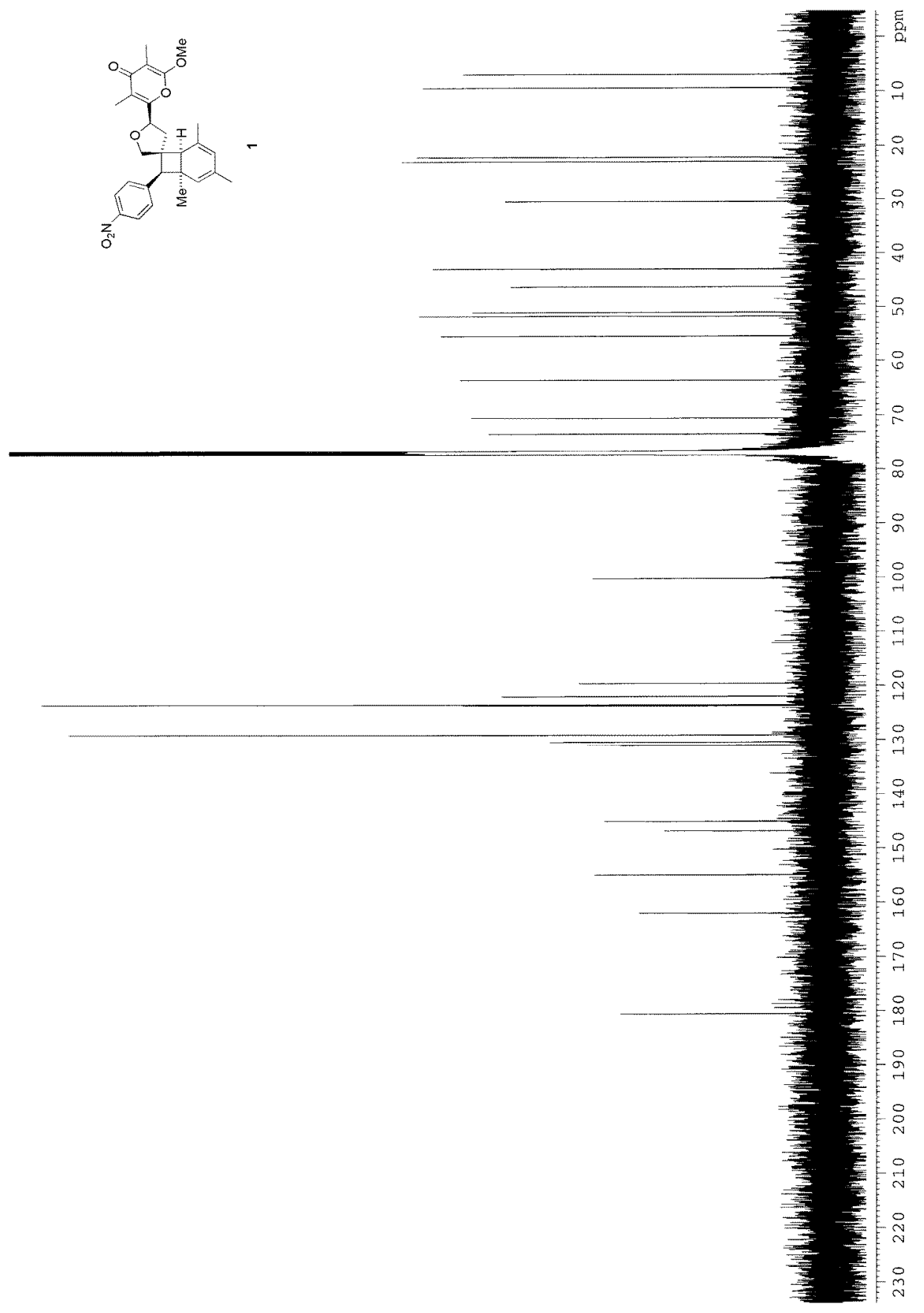




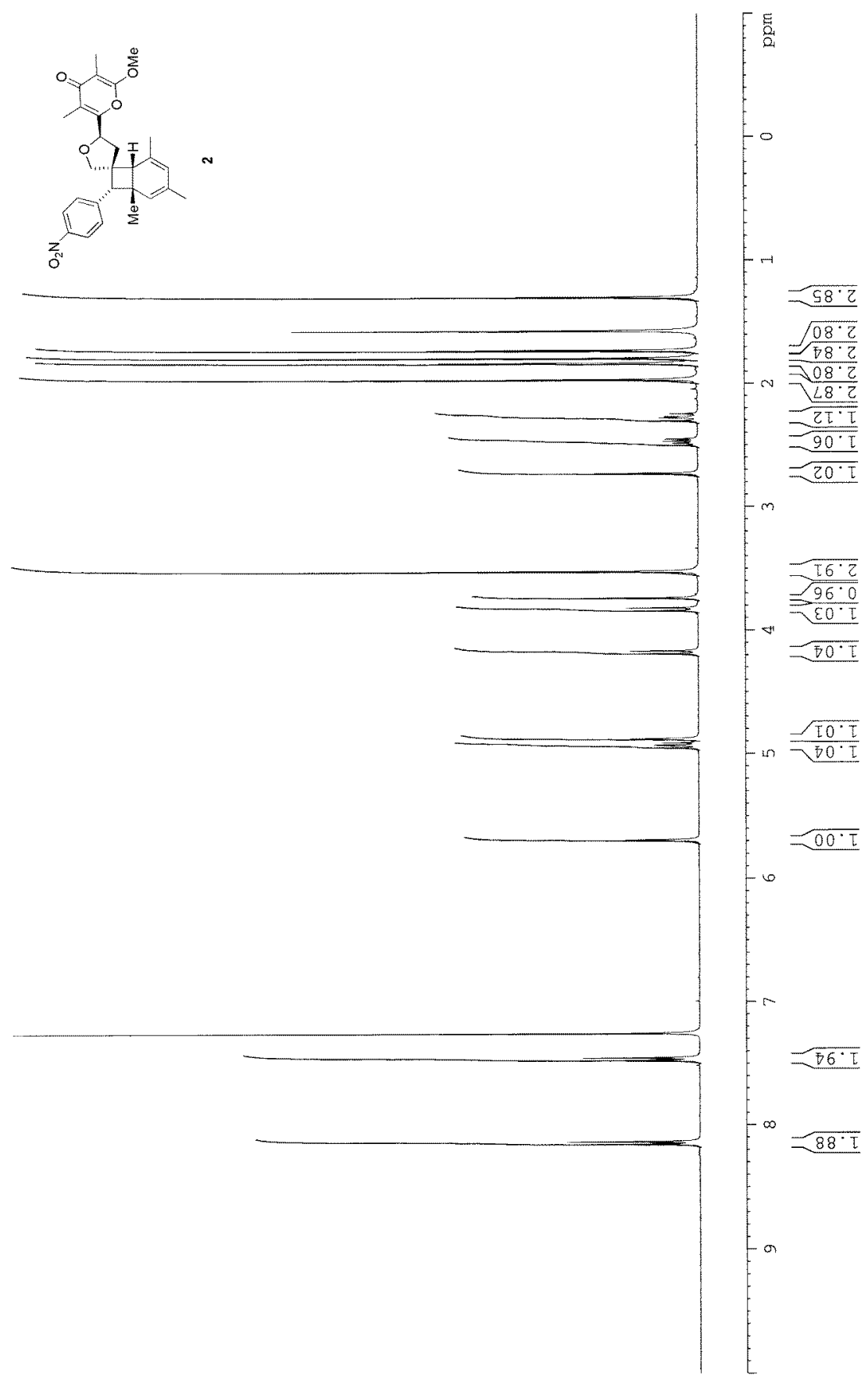




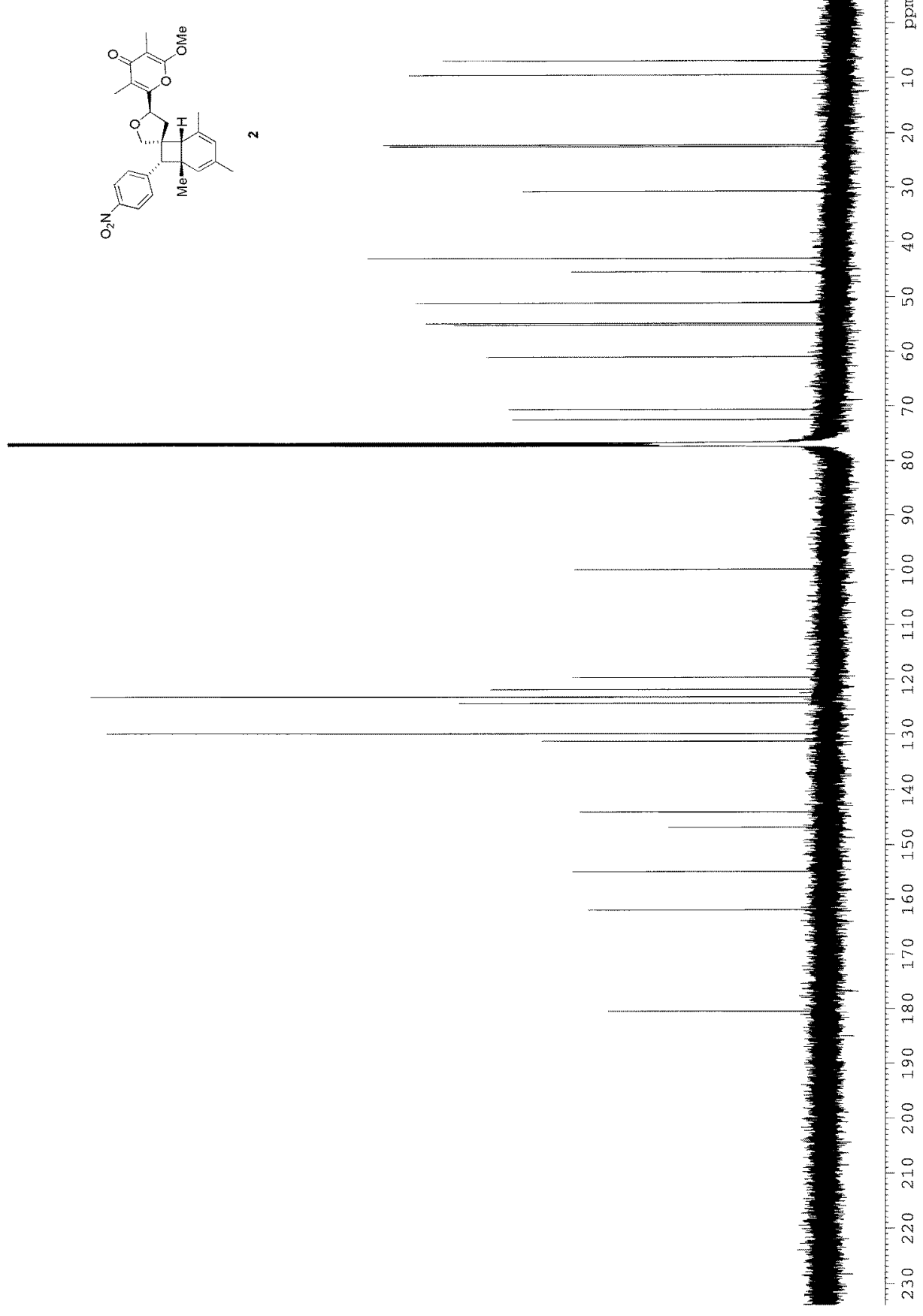

S16 


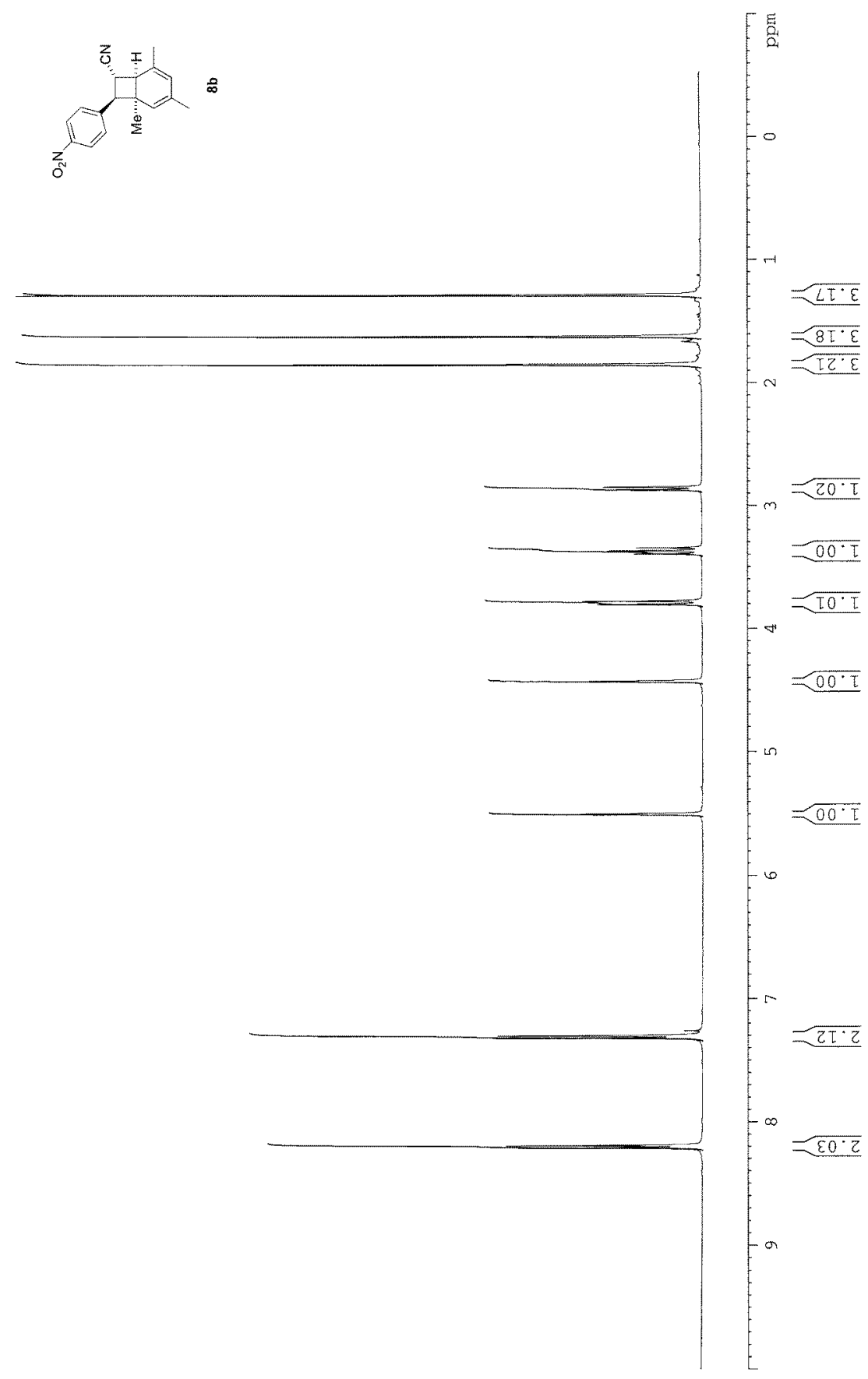




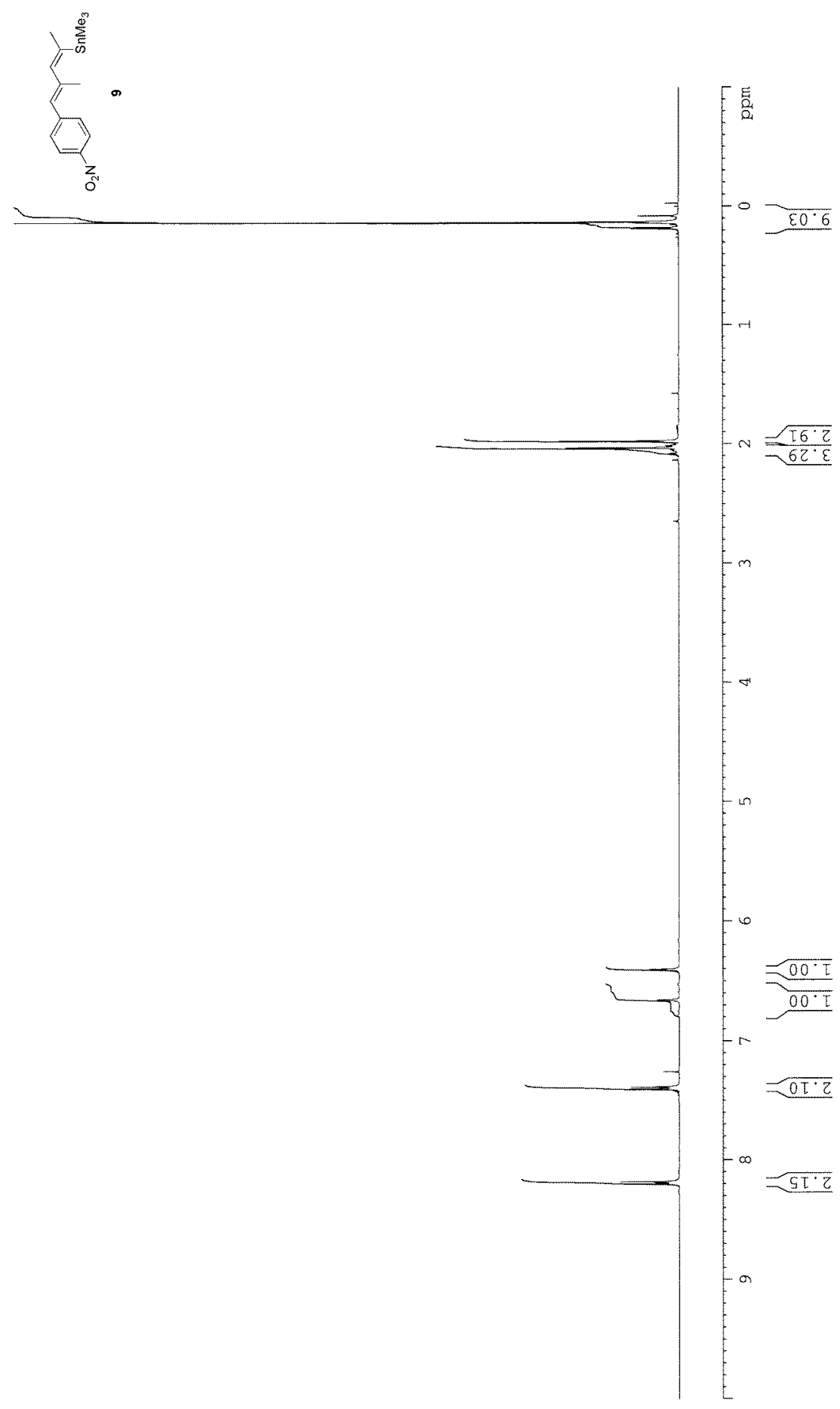




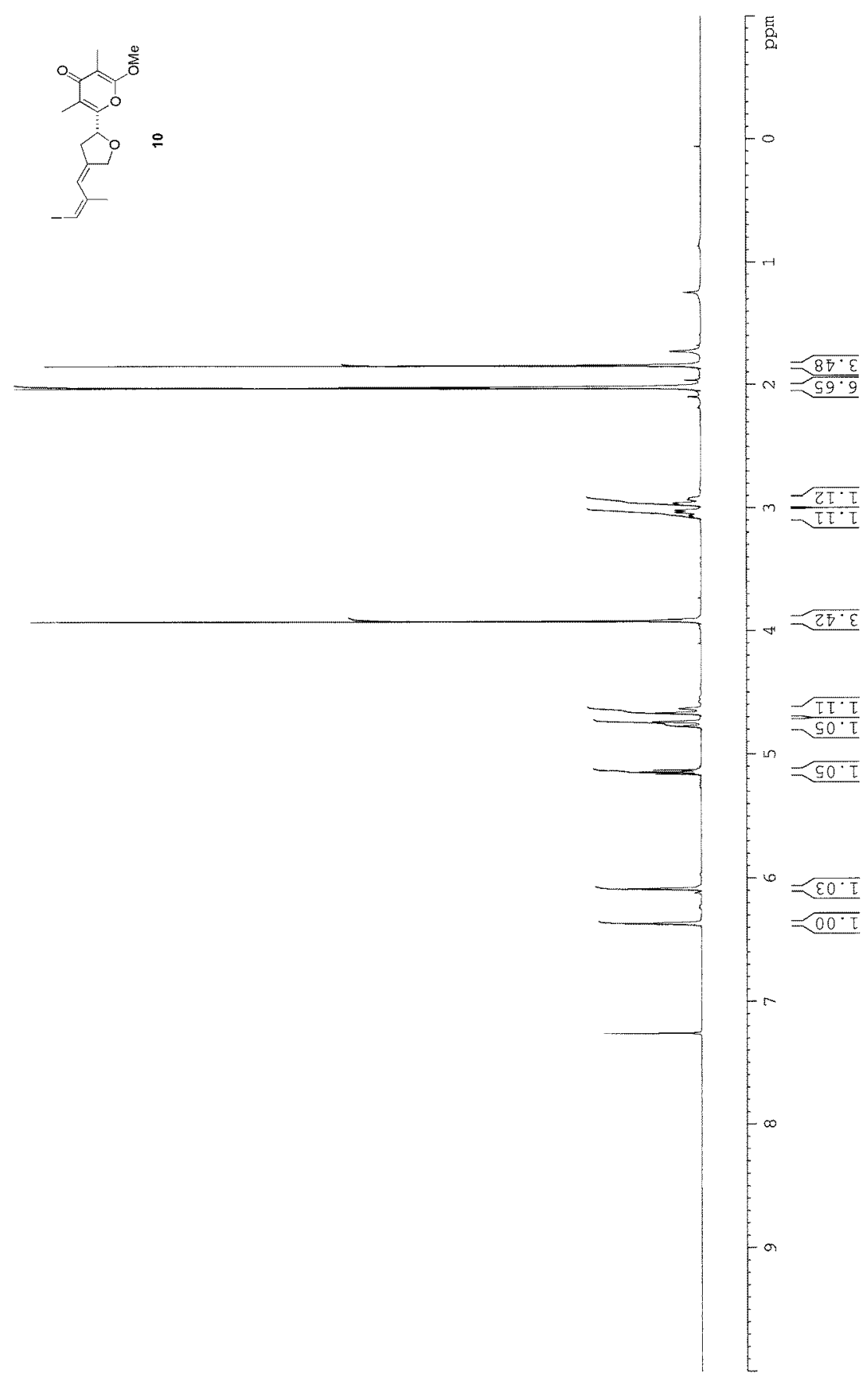




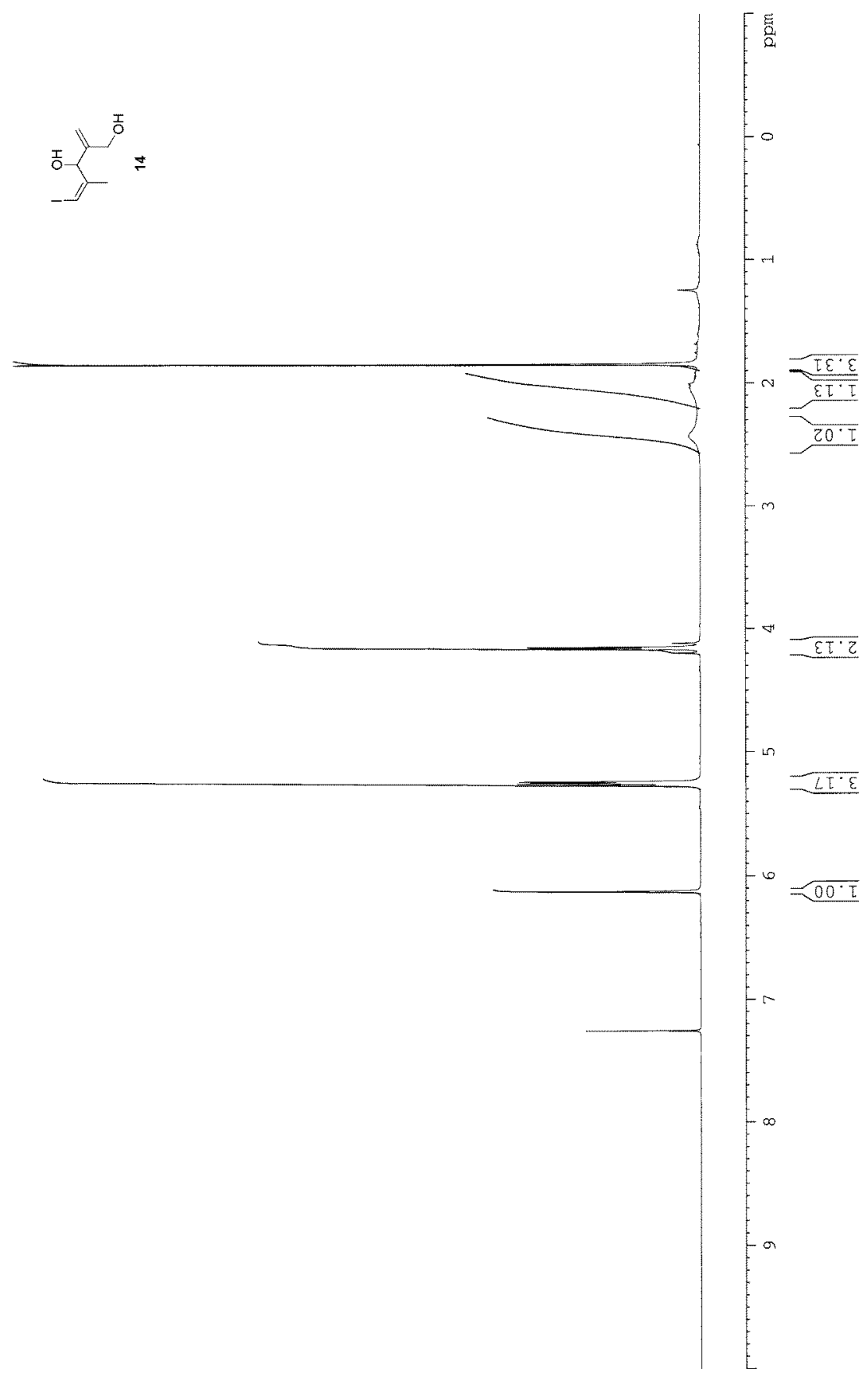



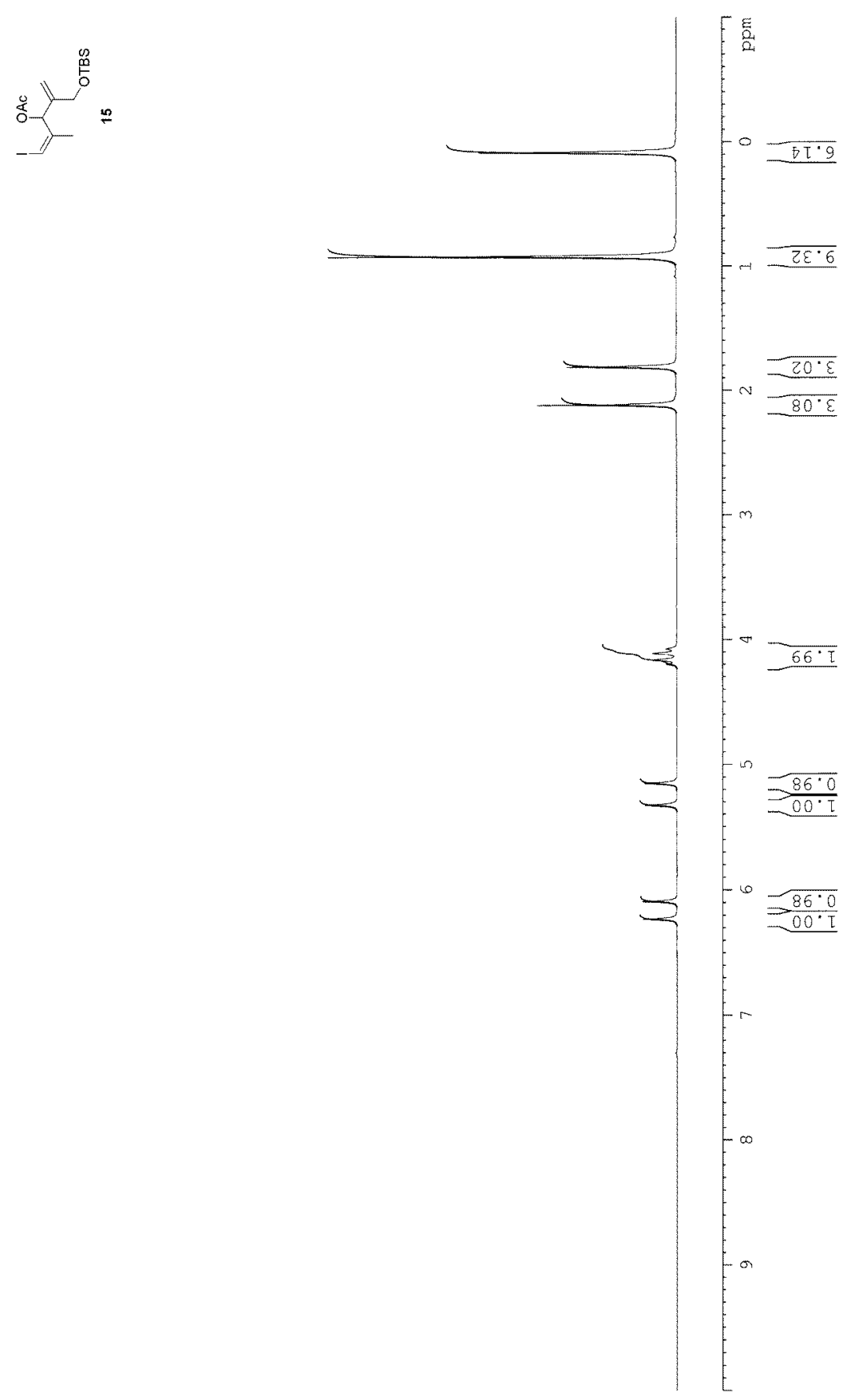


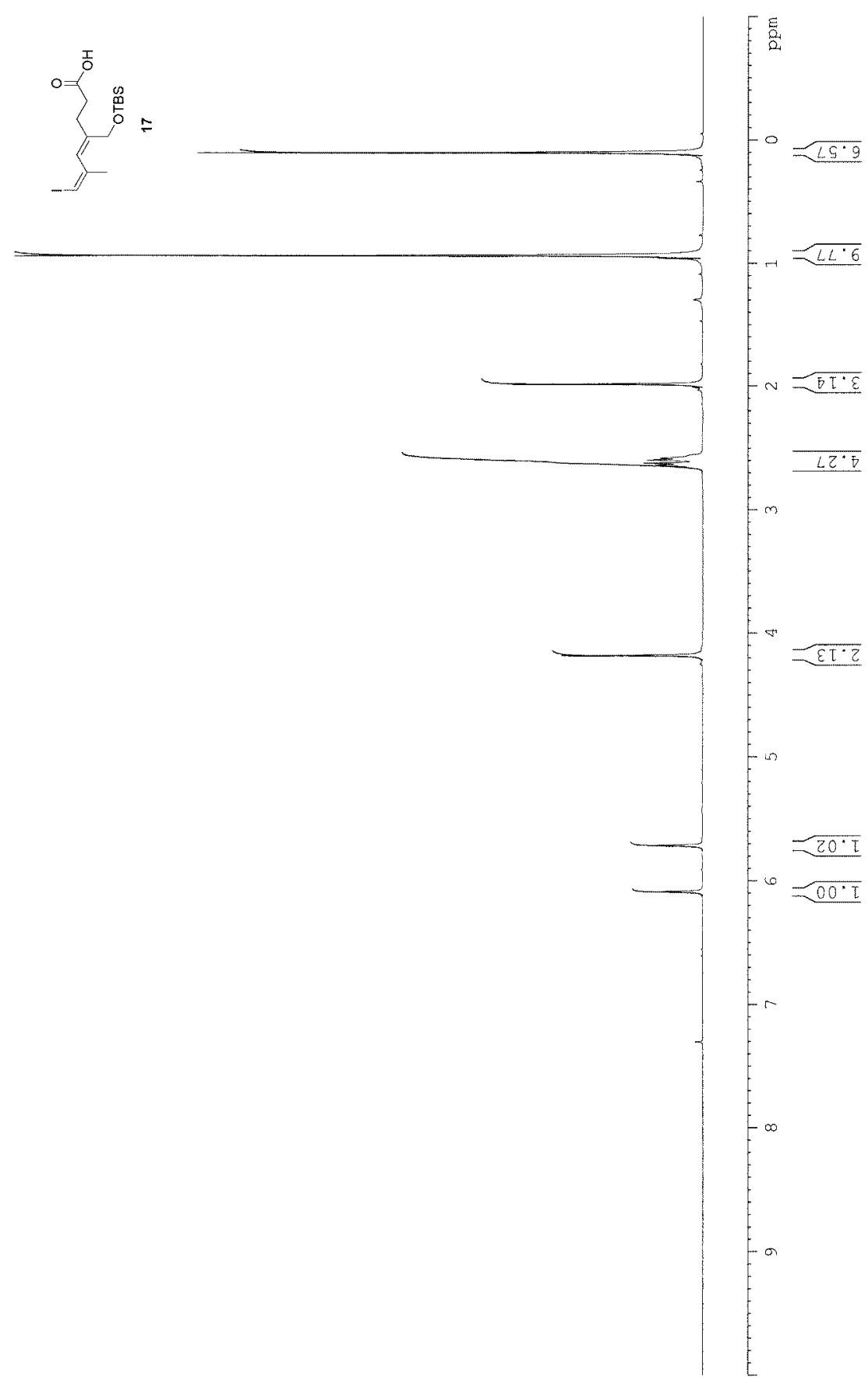




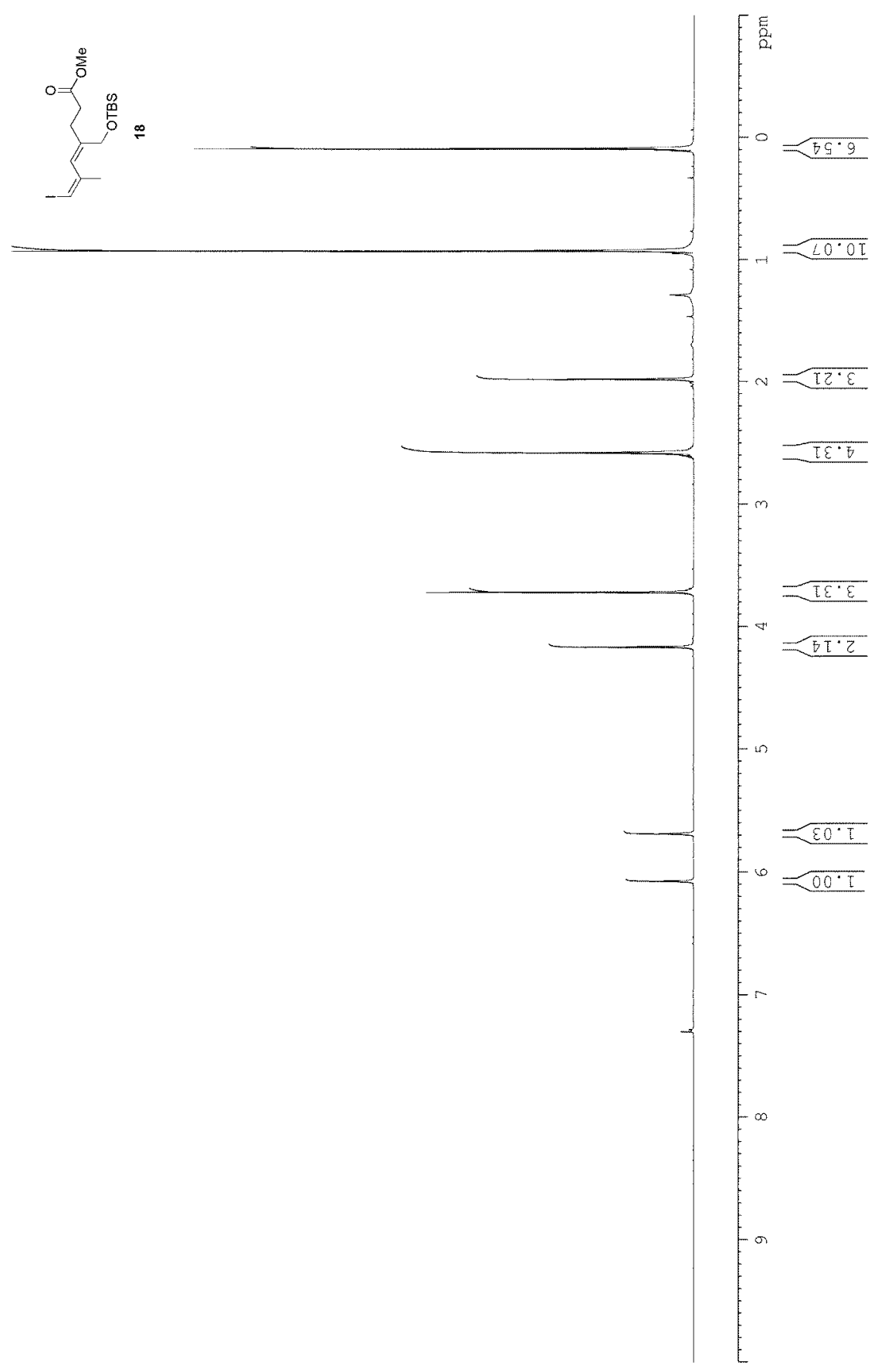




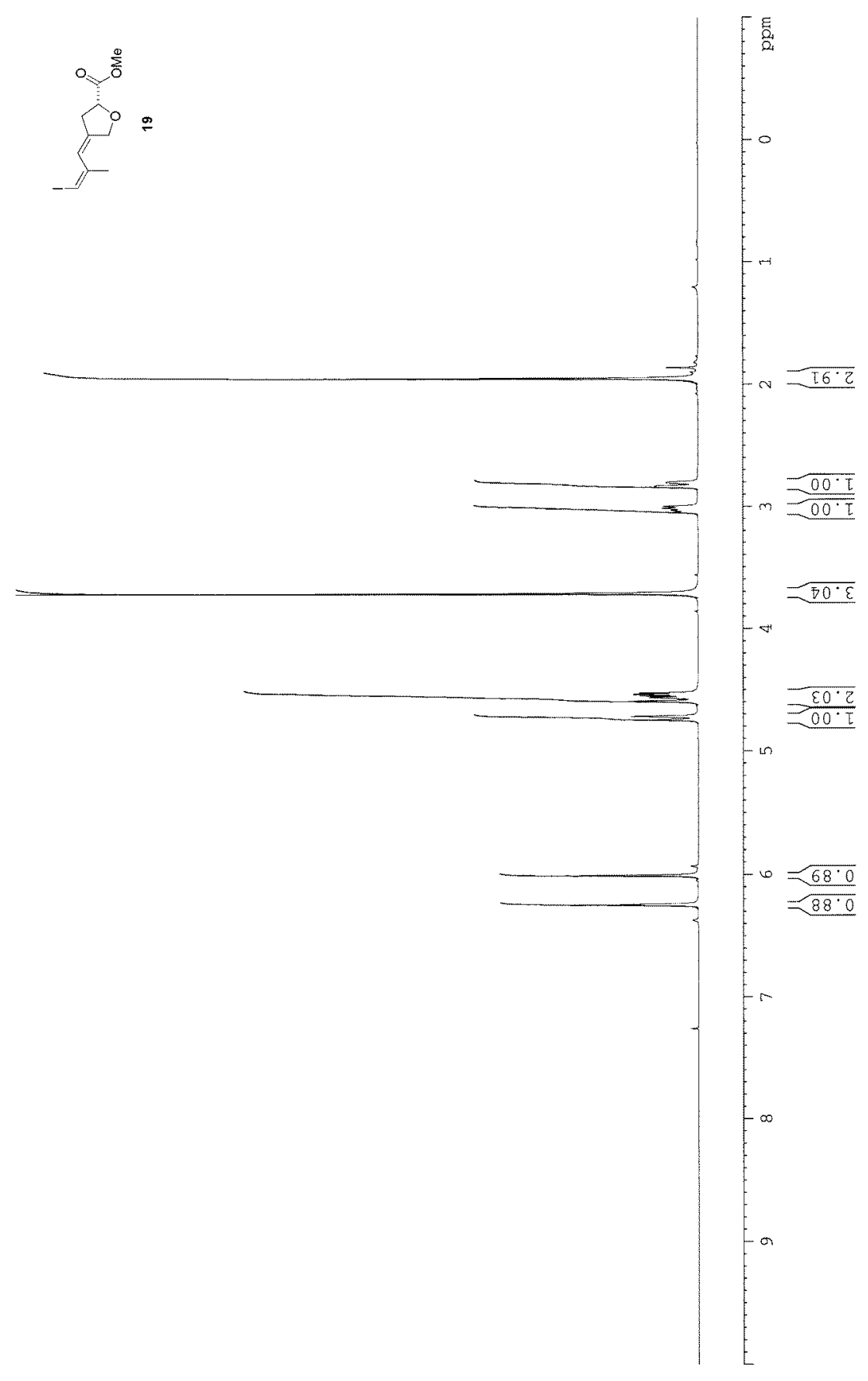




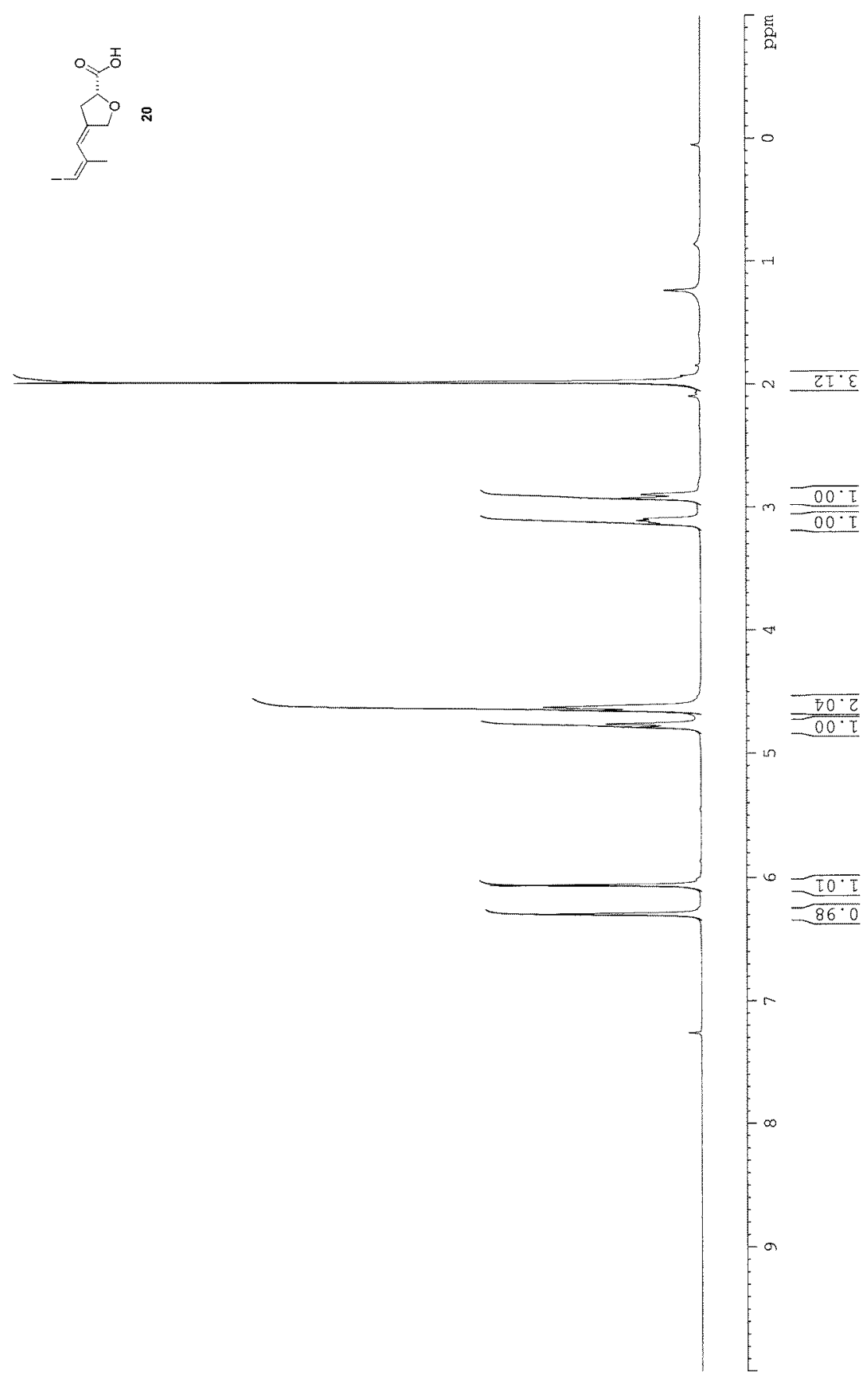




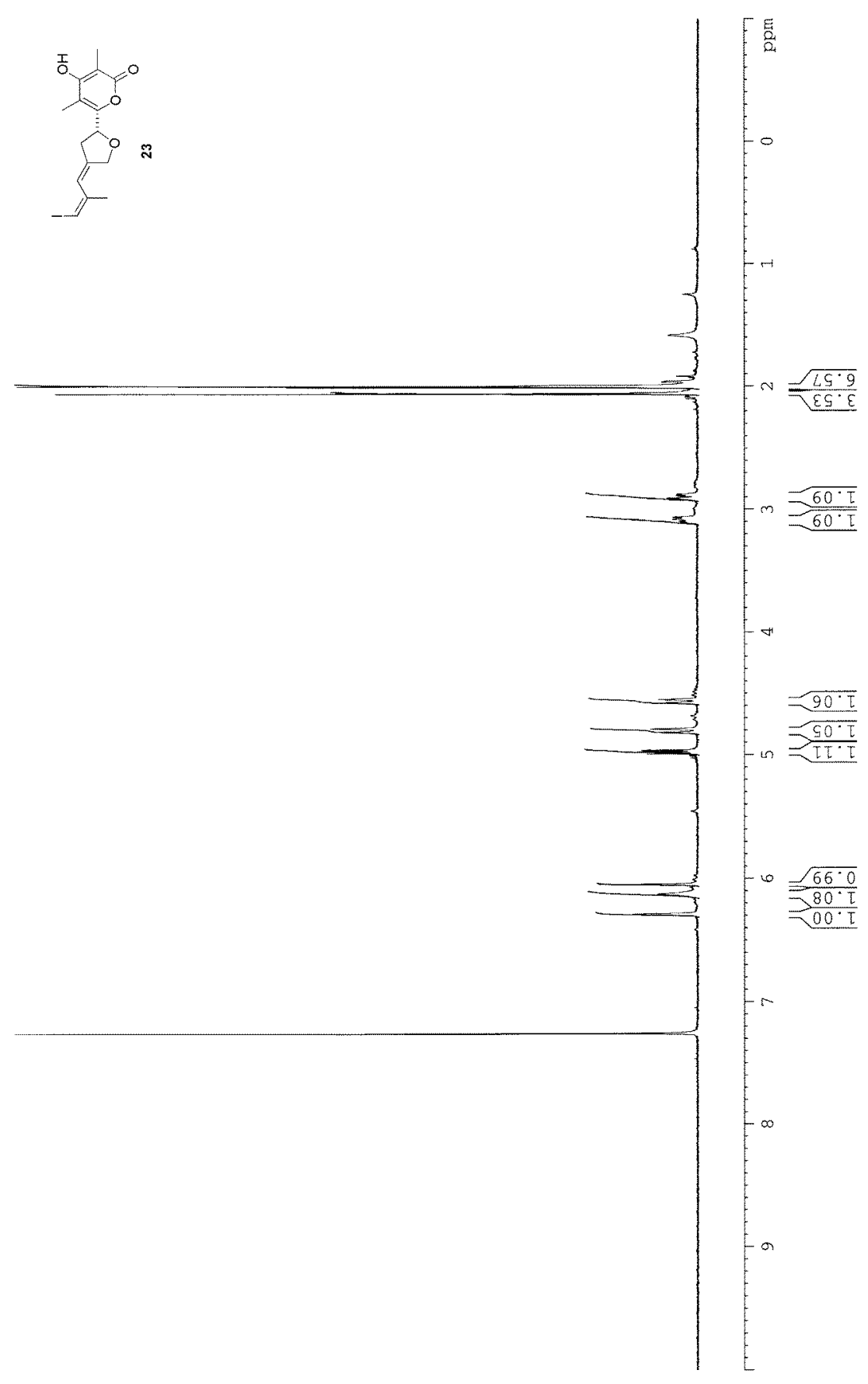




\section{ORTEP diagram of $\mathbf{8 b}$}

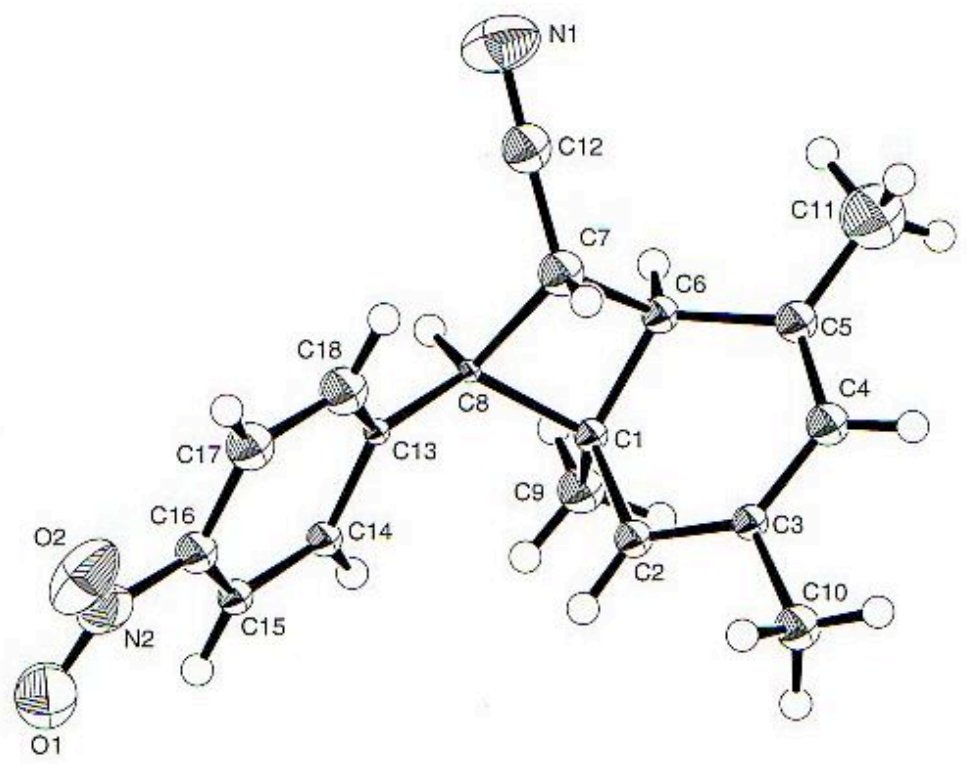

\footnotetext{
${ }^{1}$ Saito, T.; Suzuki, T.; Morimoto, M.; Akiyama, C.; Ochiai, T.; Takeuchi, K.; Matsumoto, T.; Suzuki, K. J. Am. Chem. Soc. 1998, 120, 11633.

${ }^{2}$ Beaudry, C.M.; Trauner D. Org. Lett. 2002, 4, 2221.

${ }^{3}$ Irifune, S.; Kibayashi, T.; Ishii, Y.; Ogawa, M. Synthesis 1988, 366.

${ }^{4}$ Larock, R.C.; Doty, M.J.; Han, X. J. Org. Chem. 1999, 64, 8770.
} 